Environmental Implications of Element Emissions from Phosphate-Processing Operations in Southeastern Idaho

GEOLOGICAL SURVEY PROFESSIONAL PAPER 1083
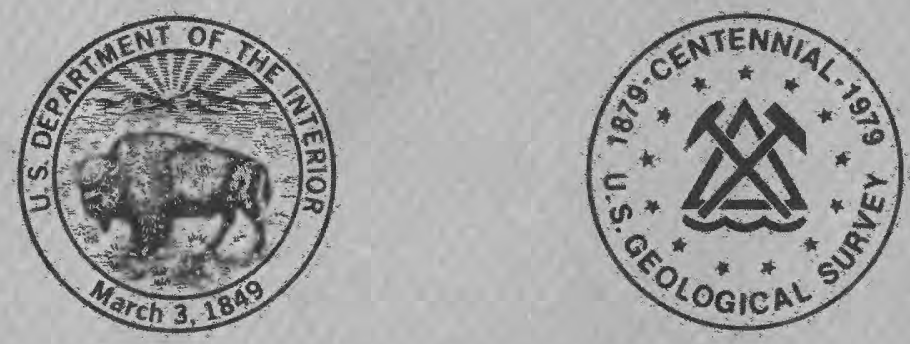


\section{Environmental Implications of Element Emissions from Phosphate-Processing Operations in Southeastern Idaho}

By R. C. SEVERSON and L. P. GOUGH

GE O L O G I A L S UR VEY P R OFESSIONAL PA PER 1083

Element concentrations in plants and soils near point sources of contamination and their possible effects on plant and animal health

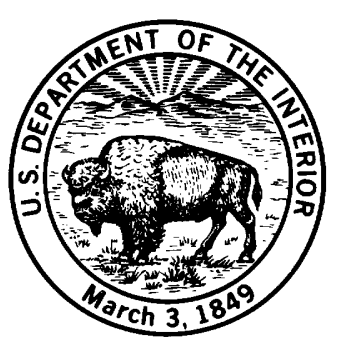




\section{UNITED STATES DEPARTMENT OF THE INTERIOR}

CECIL D. ANDRUS, Secretary

\section{GEOLOGICAL SURVEY}

\section{H. William Menard, Director}

Library of Congress Cataloging in Publication Data

Severson, Ronald Charles, 1945-

Environmental implications of element emissions from phosphate-processing operations in southeastern Idaho.

Geological Survey Professional Paper 1083

Bibliography: p. 19

1. Soil pollution-Idaho. 2. Phosphate industry-Environmental-aspects-Idaho. 3. Plants, Effect of pollution on.

4. Trace elements. I. Gough, L. P., joint author. II. Title. III. Series: United States Geological Survey Professional Paper 1083.

$\begin{array}{lll}\text { TD878.S48 } & 628.5^{\prime} 5 & 78-8949\end{array}$

For sale by the Superintendent of Documents, U.S. Government Printing Office

Washington, D.C. 20402

Stock Number 024-001-03196-5 


\section{CONTENTS}

Abstract

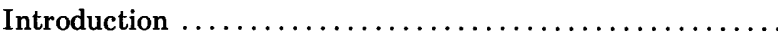

Acknowledgments .

Collection and analysis of data

Sampling design ...

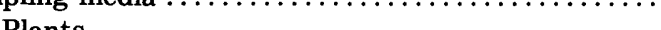

Plants .

Soils . . .

Sample preparation and chemical analysis...

Statistical analysis $\ldots \ldots \ldots \ldots \ldots \ldots \ldots \ldots \ldots \ldots \ldots \ldots$

Estimating element burden in soils . . . . . . . . . . . .
Page

1 1 1 1 1 2 2 4
5

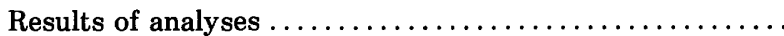
Significance of emission-related element distributions . . Element concentrations in plants . .............. Element concentrations in soils .............. Correspondence between elements in plants and soils ... Environmental implications . . . . . . . . . . . . . . . General impact of element emissions on health ....... Emission-related surface contamination of vegetation . Impact of element emissions on plant health . . . . . . . Impact of element emissions on animal health $\ldots \ldots \ldots$

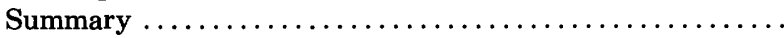

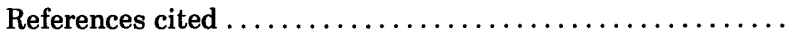

\section{ILLUSTRATIONS}

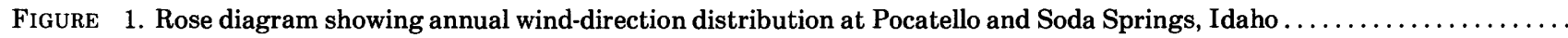

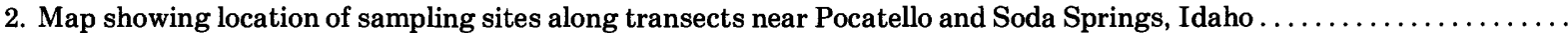

3. Photograph of the elemental-phosphorus plant and the vegetation near Pocatello, Idaho . . . . . . . . . . . . . . . . . . .

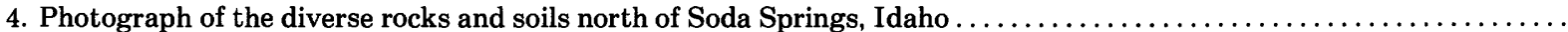

5. Graphs illustrating typical relations between element concentrations in a sampling medium and distance of sampling

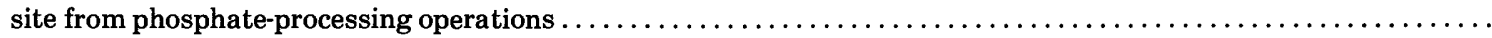

6. Diagram of major pathways in the natural migration of trace elements from phosphate-processing emissions ..........

\section{TABLES}

TABLE 1. Common and scientific plant names used in this report.

2. Analytical methods and their detection limits for element analyses in plants and soils $\ldots \ldots \ldots \ldots \ldots \ldots \ldots \ldots \ldots \ldots$

3. Detection ratios for selected elements that have some values below the limits of determination $\ldots \ldots \ldots \ldots \ldots \ldots \ldots$

4. Regression statistics for elements and ash in plants sampled near Pocatello, Idaho $\ldots \ldots \ldots \ldots \ldots \ldots \ldots \ldots \ldots \ldots$

5. Regression statistics for elements and ash in plants sampled near Soda Springs, Idaho $\ldots \ldots \ldots \ldots \ldots \ldots \ldots \ldots \ldots \ldots$

6. Regression statistics for elements in soils sampled near Pocatello, Idaho $\ldots \ldots \ldots \ldots \ldots \ldots \ldots \ldots \ldots \ldots \ldots \ldots$

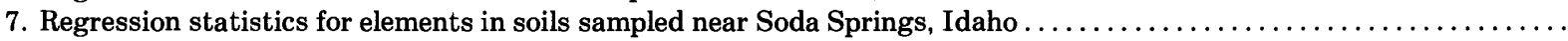

8. Comparison of the estimated concentrations of selected trace elements in big sagebrush, cheatgrass, and bluebunch wheatgrass at distances of $3 \mathrm{~km}$ from phosphate-processing sites at Pocatello and Soda Springs, Idaho ..........

9. Estimated element concentrations in surface soils northeast (downwind) of phosphate-processing sites near Pocatello, Idaho, and average concentration of elements in soils as reported in the literature $\ldots \ldots \ldots \ldots \ldots \ldots \ldots \ldots$

10. Correlations between element concentrations in plants and in A-horizon soils along transects beginning near phosphate-

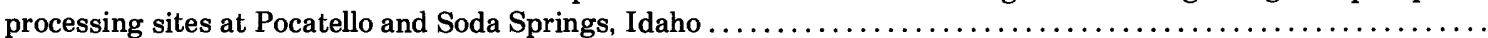

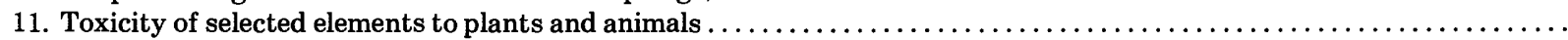

12. Chemistry of washed and unwashed bluebunch wheatgrass samples collected $2 \mathrm{~km}$ downwind from an elemental-phos-

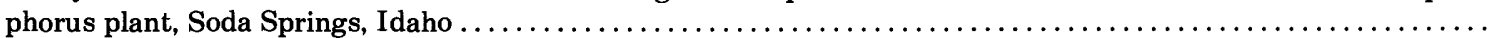





\title{
ENVIRONMENTAL IMPLICATIONS OF ELEMENT EMISSIONS FROM PHOSPHATE-PROCESSING OPERATIONS IN SOUTHEASTERN IDAHO
}

\author{
By R. G. Severson and L. P. GOUGH
}

\begin{abstract}
In order to assess the contribution to plants and soils of certain elements emitted by phosphate processing, we sampled sagebrush, grasses, and A- and C-horizon soils along upwind and downwind transects at Pocatello and Soda Springs, Idaho. Analyses for 70 elements in plants showed that, statistically, the concentration of 7 environmentally important elements, cadmium, chromium, fluorine, selenium, uranium, vanadium, and zinc, were related to emissions from phosphate-processing operations. Two additional elements, lithium and nickel, show probable relationships. The literature on the effects of these elements on plant and animal health is briefly surveyed. Relations between element content in plants and distance from the phosphate-processing operations were stronger at Soda Springs than at Pocatello and, in general, stronger in sagebrush than in the grasses. Analy ses for 58 elements in soils showed that, statistically, beryllium, fluorine, iron, lead, lithium, potassium, rubidium, thorium, and zinc were related to emissions only at Pocatello and only in the A horizon. Moreover, six additional elements, copper, mercury, nickel, titanium, uranium, and vanadium, probably are similarly related along the same transect. The approximate amounts of elements added to the soils by the emissions are estimated. In C-horizon soils, no statistically significant relations were observed between element concentrations and distance from the processing sites. At Soda Springs, the nonuniformity of soils at the sampling locations may have obscured the relationship between soil-element content and emissions from phosphate processing.
\end{abstract}

\section{INTRODUCTION}

In phosphate processing, the mechanical operations of grinding, sorting, and drying, as well as the chemical and thermal processes of calcination and beneficiation, may release into the atmosphere the potentially toxic and therefore environmentally important elements cadmium, chromium, fluorine, lead, lithium, mercury, nickel, selenium, silver, uranium, vanadium, and zinc. Ore stockpiles, slag, and settling ponds can also serve as sources of wind-blown contaminants and, therefore, we consider processing sites and not strictly stack emissions as the source area of emitted elements. Except for fluorine (University of Idaho, 1955-74), no studies have been made to evaluate the contribution, if any, of these elements to local plants and soils in the southeastern Idaho phosphate-processing areas. Therefore, we conducted this study in May 1975 to assess the impact of element emissions on selected plants and soils by comparing the element concentrations in samples with distance of sampling sites upwind and downwind from these operations at Pocatello and Soda Springs. Our second goal was to delineate zones of maximum influence along selected transects. Our final goal was to apply our findings to the analysis of potential, but unproven, effects of the emitted elements on the present and future health of plants, animals, and humans located within the zones of influence.

Interest in the health-related aspects of biologically active trace elements has expanded greatly during the past 30 years. Comparisons of data from the present study with examples of trace-element toxicity to plants and animals reported in the literature (for example, Gough and Shacklette, 1976) suggest the potential health effects of element emissions from phosphate processing.

\section{ACKNOWLEDGMENTS}

For preparing samples and performing chemical analyses, we thank David Bickford, W. E. Cary, Nancy M. Conklin, Johnnie M. Gardner, T. F. Harms, A. W. Haubert, R. G. Havens, Claude Huffman, Jr., L. M. Lee, R. E. McGregor, V. M. Merritt, H. T. Millard, Jr., C. S. E. Papp, Ida Price, L. B. Riley, V. E. Shaw, J. A. Thomas, R. E. Van Loenen, and J. S. Wahlberg. We also thank George VanTrump, Jr., for his valuable service in computer programing, J. J. Connor, A. T. Miesch, and H. T. Shacklette for their critical reviews and helpful suggestions throughout the study, and R. $W$. White (deceased) for assistance in mineral identification.

\section{COLLECTION AND ANALYSIS OF DATA SAMPLING DESIGN}

Sampling was designed to determine whether the element content of selected plants and soils decreased 
systematically with increasing distance from processing sites at Pocatello and Soda Springs, and if so, which decreases could be demonstrated at an acceptable confidence level. Transects originating at and extending in two directions from the processing sites were established in relation to the predominant wind vectors (fig. 1). At Pocatello, the predominant winds are from the southwest; at Soda Springs, the frequency of winds from the southeast and northwest is about equal. Six points representing ideal sampling locations were selected along each transect at increasing geometric intervals away from the processing sites, the nearest point being $2 \mathrm{~km}$, and the farthest, $64 \mathrm{~km}$. The actual locations (fig. 2) deviated from the preselected points according to the availability of the desired sampling media. At each location, paired samples of two plants and two soil horizons were collected within $100 \mathrm{~m}$ of each other.

\section{SAMPLING MEDIA PLANTS}

Sagebrush Steppe (Küchler, 1964) is the dominant plant community in the eastern Snake River Plain near Pocatello and in the valleys around Soda Springs. The phosphate-processing sites are in this community, and ranching and dryland farming are also concentrated here. At Pocatello, we collected basin big sagebrush,

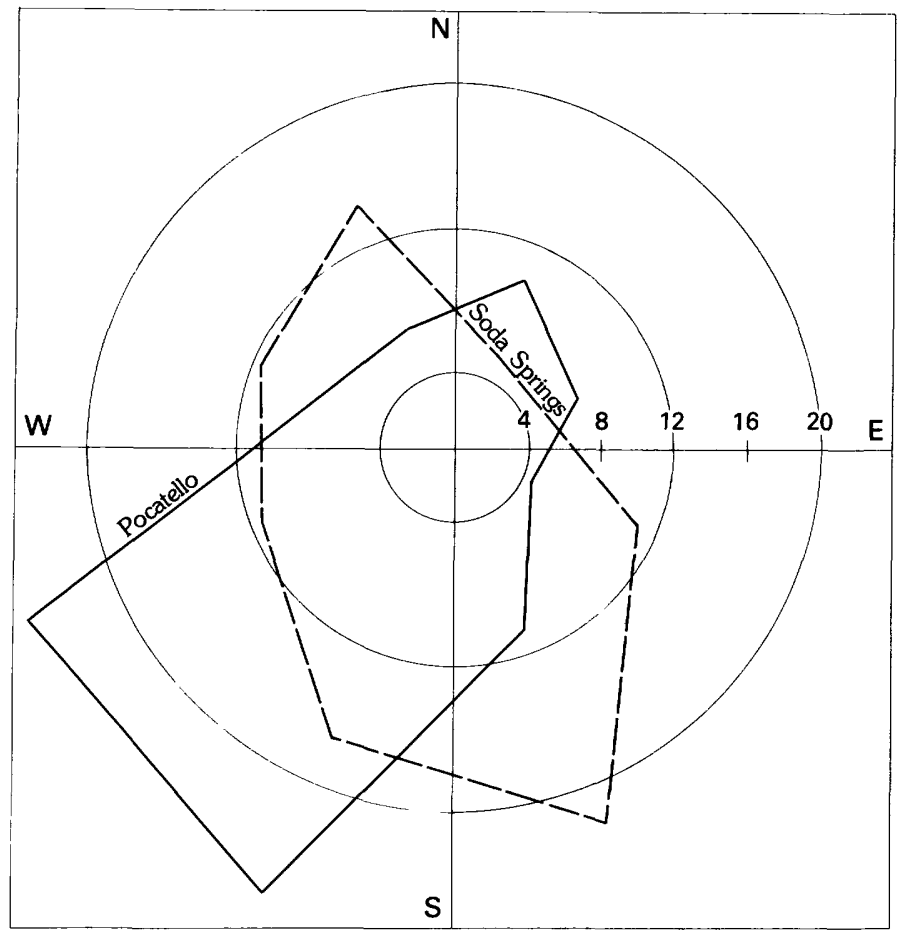

FIgURE 1.-Annual wind-direction distribution at Pocatello and Soda Springs, Idaho. Numbered scale indicates the percent frequency for a given wind direction. Modified from Cramer and Bowers, 1974. the dominant shrub, and cheatgrass, the dominant annual grass (fig. 3). (See table 1 for scientific names of plants cited by common name in this report.) At Soda Springs, the sagebrush we collected included some mountain big sagebrush and some basin big sagebrush. Because of differences in the overall climate of the two areas and because samples were collected in early spring, cheatgrass was not found at Soda Springs; however, bluebunch wheatgrass was abundant and was sampled. When we collected the latter samples, we could not positively identify the grass species because there were no diagnostic fertile culms. However, a return visit to the exact collecting sites by one of us (Gough) in September 1976 enabled us to confirm that the analysis samples were primarily bluebunch wheatgrass and some rough fescue.

Paired samples of sagebrush and grass were collected at each sampling location at both Pocatello and Soda Springs (fig. 2), except at the sampling location in an agricultural-residential area $3 \mathrm{~km}$ north of Pocatello where sagebrush was absent.

Samples included the terminal 8 to $12 \mathrm{~cm}$ of the stems (including leaves and flowers) of sagebrush at Pocatello and Soda Springs, the leaves, stems, and flowers of cheatgrass at Pocatello, and the leaves and stems of the bluebunch wheatgrass at Soda Springs. Only plants that appeared to be healthy were sampled.

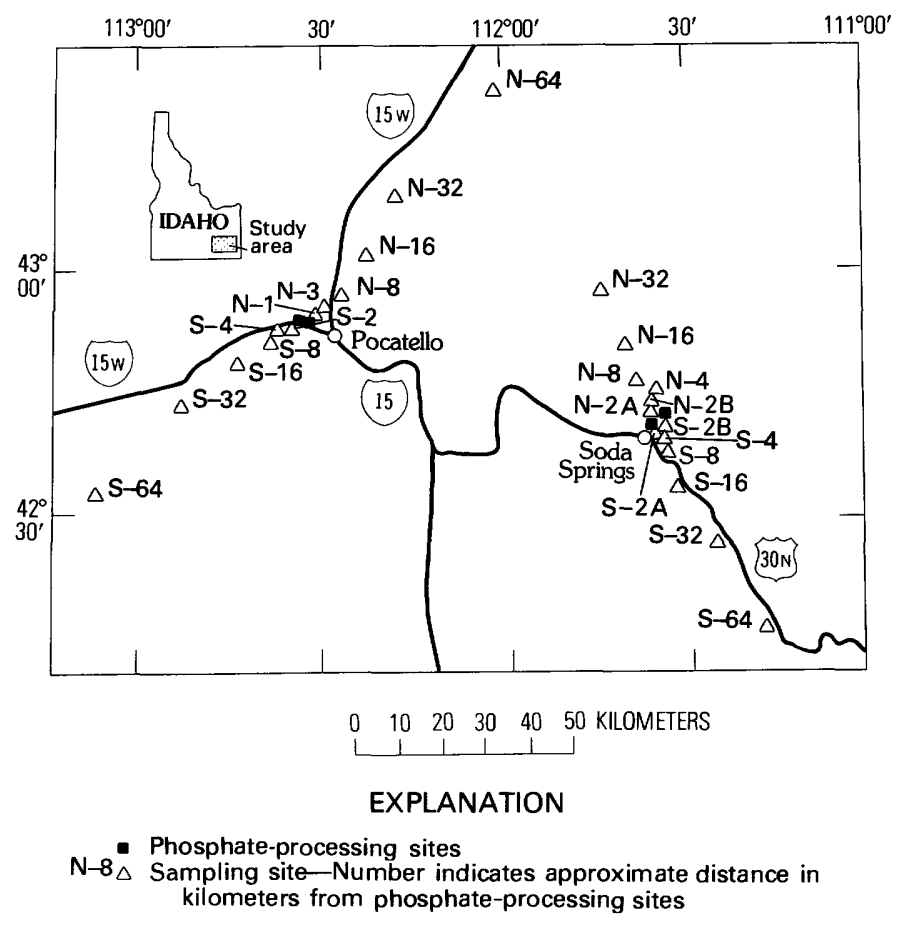

Figure 2.-Location of sampling sites along transects near Pocatello and Soda Springs, Idaho. 


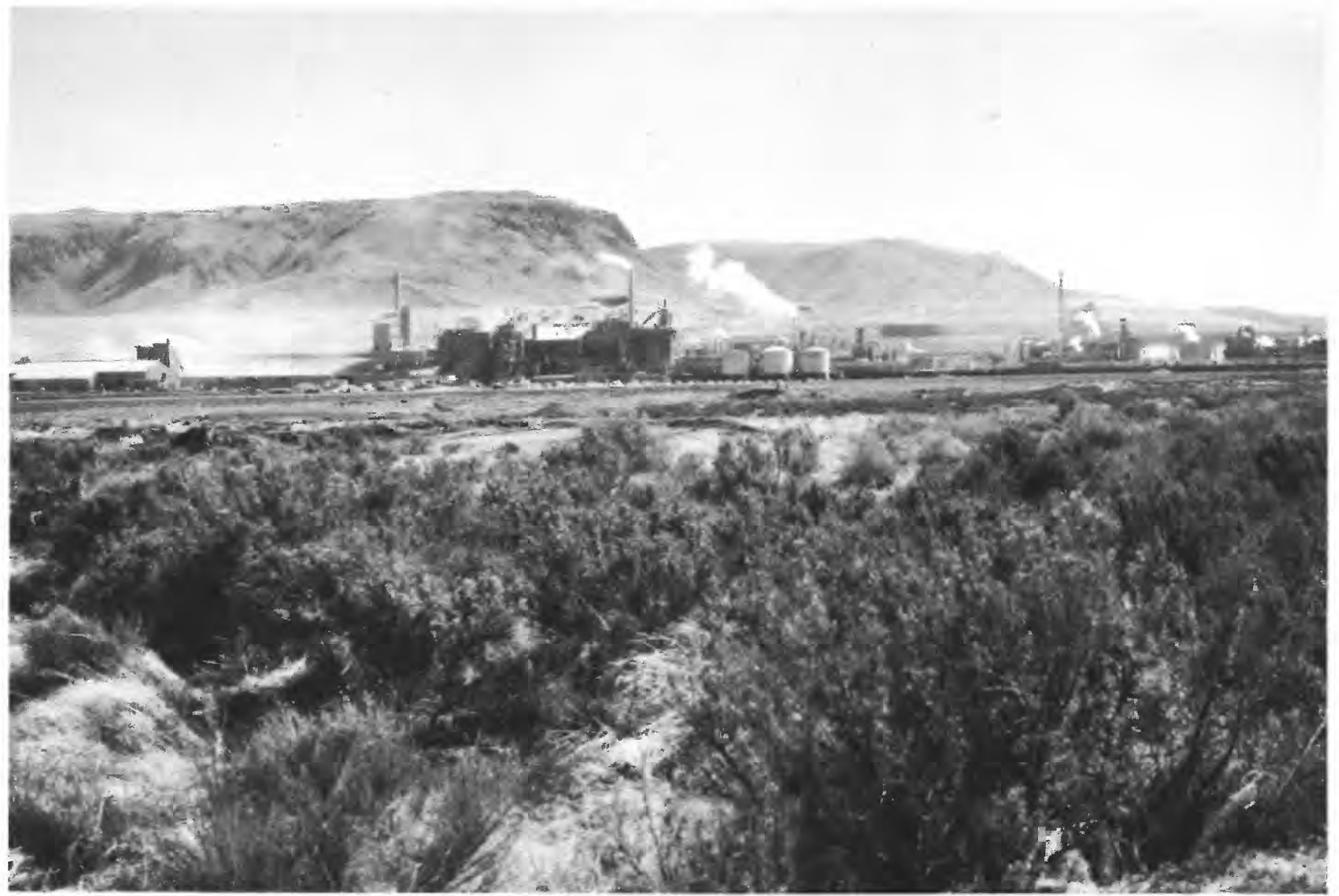

FIGURE 3.-Elemental-phosphorus processing plant at Pocatello,Idaho. Vegetation in the foreground is almost exclusively big sagebrush (Artemisia tridentata) and cheatgrass (Bromus tectorum). Photographed May 16, 1975.

SOILS

Paired samples of both A- and C-horizon soils, defined according to traditional usage (U.S. Department of Agriculture, 1962, p. 173-188), were collected at each sampling location. The paired samples from the $\mathrm{C}$ horizon were combined at each location in the field to yield one sample. The A horizon was sampled by removing plant debris from the surface of the ground and excavating with a garden spade to a depth of about $5 \mathrm{~cm}$. The $\mathrm{C}$ horizon was sampled by hand augering to the necessary depth and saving, to the extent possible, the centermost part of the auger core. Depth of sampling of this horizon was controlled by the character of the soil at individual sites-at places samples were as shallow as $50 \mathrm{~cm}$ where the underlying rock was near the surface or where the composition of the parent material changed. Most C-horizon samples were from depths of 80 to $100 \mathrm{~cm}$.

Soils sampled along the transects near Pocatello are remarkably uniform. These soils developed from relatively unweathered aeolian sediments derived from the Snake River flood plain, and they range in thickness from less than 50 to more than $200 \mathrm{~cm}$ (Lewis and others, 1975). Conversely, the soils near Soda Springs are highly variable in character (Youngs and others, 1925). Those sampled had developed on such varied parent materials as limestone residuum, aeolian sediments, basalt, valley-fill material of stream origin, and colluvium (fig. 4).

\section{SAMPLE PREPARATION AND CHEMICAL ANALYSIS}

Plant samples were cleaned, pulverized, and dry ashed. Cleaning consisted of agitation in tap water, followed by ultrasonic agitation in deionized distilled water. After cleaning, the samples were dried in an oven at about $38^{\circ} \mathrm{C}$ and were then pulverized in a Wiley mill to pass through a $1.3-\mathrm{mm}$-mesh screen. The pulverized samples were dry ashed in a muffle furnace at $500^{\circ} \mathrm{C}$ for about 24 hours, and the ash was used for analysis of most elements. Pulverized samples were prepared for fluorine and selenium analysis by wet digestion. 
TABLE 1.-Common and scientific plant names used in this report

\begin{tabular}{|c|c|}
\hline Common name & Scientific name \\
\hline 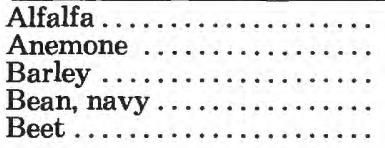 & $\begin{array}{l}\text { Medicago sativa } \mathrm{L} . \\
\text { Pulsatilla patens }(\mathrm{L} .) \text { Mill. } \\
\text { Hordeum vulgare } \mathrm{L} \text {. } \\
\text { Phaseolus vulgaris } \mathrm{L} \text {. } \\
\text { Beta vulgaris } \mathrm{L} \text {. }\end{array}$ \\
\hline 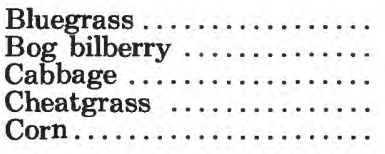 & $\begin{array}{l}\text { Poa sp. } \\
\text { Vaccinium uliginosum } \mathrm{L} \text {. } \\
\text { Brassica oleracea var. capitata } \mathrm{L} \text {. } \\
\text { Bromus tectorum } \mathrm{L} \text {. } \\
\text { Zea mays } \mathrm{L} \text {. }\end{array}$ \\
\hline 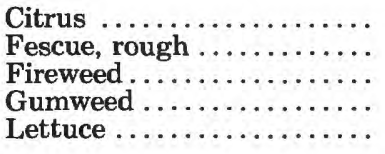 & $\begin{array}{l}\text { Citrus sp. } \\
\text { Festuca scabrella Torr. } \\
\text { Epilobium angustifolium } \mathrm{L} . \\
\text { Grindelia aphanactis Rydb. } \\
\text { Lactuca sativa } \mathrm{L} .\end{array}$ \\
\hline 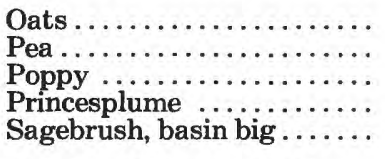 & $\begin{array}{l}\text { Avena sativa } \mathrm{L} . \\
\text { Pisum sativum } \mathrm{L} \text {. } \\
\text { Papaver macrostomum B. et } \mathrm{H} . \\
\text { Stanleya pinnata (Pursh) Britt. } \\
\text { Artemisia tridentata Nutt. subsp. }\end{array}$ \\
\hline Sagebrush, mountain big... & $\begin{array}{l}\text { Artemisia tridentata subsp. } \\
\text { vaseyana (Rydb.) Beetle }\end{array}$ \\
\hline 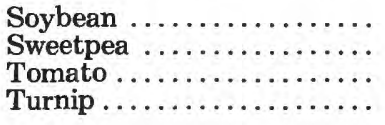 & $\begin{array}{l}\text { Glycine max Merr. } \\
\text { Lathyrus sp. } \\
\text { Lycopersicum esculentum Mill. } \\
\text { Brassica napus L. }\end{array}$ \\
\hline $\begin{array}{l}\text { Violet } \ldots \ldots \ldots \ldots \ldots \ldots \ldots \\
\text { Wheat ........................... } \\
\text { Wheatgrass, bluebunch .... }\end{array}$ & $\begin{array}{l}\text { Viola sp. } \\
\text { Triticum spp. } \\
\text { Agropyron spicatum (Pursh) Scribn. } \\
\text { and Smith }\end{array}$ \\
\hline
\end{tabular}

Analyses of these two elements are expressed on a dryweight basis, whereas all other analyses are expressed on an ash-weight basis.

The mineralogy of the wash residue from samples of bluebunch wheatgrass, collected $2 \mathrm{~km}$ northwest (downwind) of the elemental-phosphorus plant at Soda Springs, was examined by X-ray diffraction techniques. The dry residue was ground using a mortar and pestle and the resulting powders were $\mathrm{X}$-rayed on a diffractometer using $\mathrm{CuK}_{\alpha}$ radiation. Diffraction patterns were recorded for each powder over a $2 \theta$ range of $2^{\circ}$ to about $55^{\circ}$ at a rate of $2^{\circ}$ per minute.

Soil samples were dried under forced air at ambient temperature, and the dried material was passed through a 2-mm-mesh sieve. The minus-2-mm fraction was further ground to pass a 100 -mesh sieve $(150 \mu \mathrm{m}$ openings), and this material was used for all analytical determinations.

All sample preparations and analytical determinations for both plant and soil materials were done in U.S. Geological Survey laboratories at Denver, Colo. The analyses of plant materials followed the procedures for specific analytical methods, other than emission spectrography, described by Harms and Papp (1975). Soil analyses followed the X-ray fluorescence procedures described by Wahlberg (1975), the neutron activation procedures described by Millard (1975), and the atomic absorption spectroscopy procedures described by Huffman (1975). Meyers, Havens, and Dunton (1961) described the emission spectrography analytical technique used for both plants and soils. Table 2 lists the analytical method and the detection limit for each element in each sampling medium.

\section{STATISTICAL ANALYSIS}

The error associated with sample preparation and analysis was evaluated by examining duplicate analytical determinations from splits of samples that were randomly selected from the complete sample suite. All samples of plants or soils, including the splits, were then placed in a randomized sequence and submitted for analysis. Analysis of the samples in this sequence randomizes any systematic bias that may result from the analytical and sample-handling procedures. Analysis of variance was then used to estimate the relative error variance due to sample preparation and analysis, according to the technique of Miesch (1967). Sample preparation and analysis caused excessive error variance in the data for lead and molybdenum in plants and for antimony, arsenic, barium, boron, germanium, lanthanum, phosphorus, scandium, strontium, yttrium, and zirconium in soils (Severson and Gough, 1976); these elements were not examined further.

Some elements in plant and soil material were not detectable by the analytical methods used. If an element was not detectable in one-fourth or more of the total number of plant or soil samples, the data were not examined further in this study. If an element was not detected in only a few samples of either plants or soils (table 3), the concentration of the element in these samples was considered to be equal to seven-tenths of the lower detection limit. (The justification for these substitutions is discussed by Severson and Gough, 1976.)

Variations of element concentrations in plants and soils, relative to distance from each phosphateprocessing site, were examined by linear regression. The regression model was of the form:

$$
\log _{10} X=b_{0}+b_{1} \log _{10} D
$$

where $X$ is the concentration of the element, $D$ is the distance from the processing site, and $b_{0}$ and $b_{1}$ are, respectively, the regression constant and regression coefficient. The statistical significance of each regression was determined by analysis of variance procedures (for example, Davis, 1973, p. 192-204). Coefficients of determination between log element concentration and log distance provide estimates of the propor- 


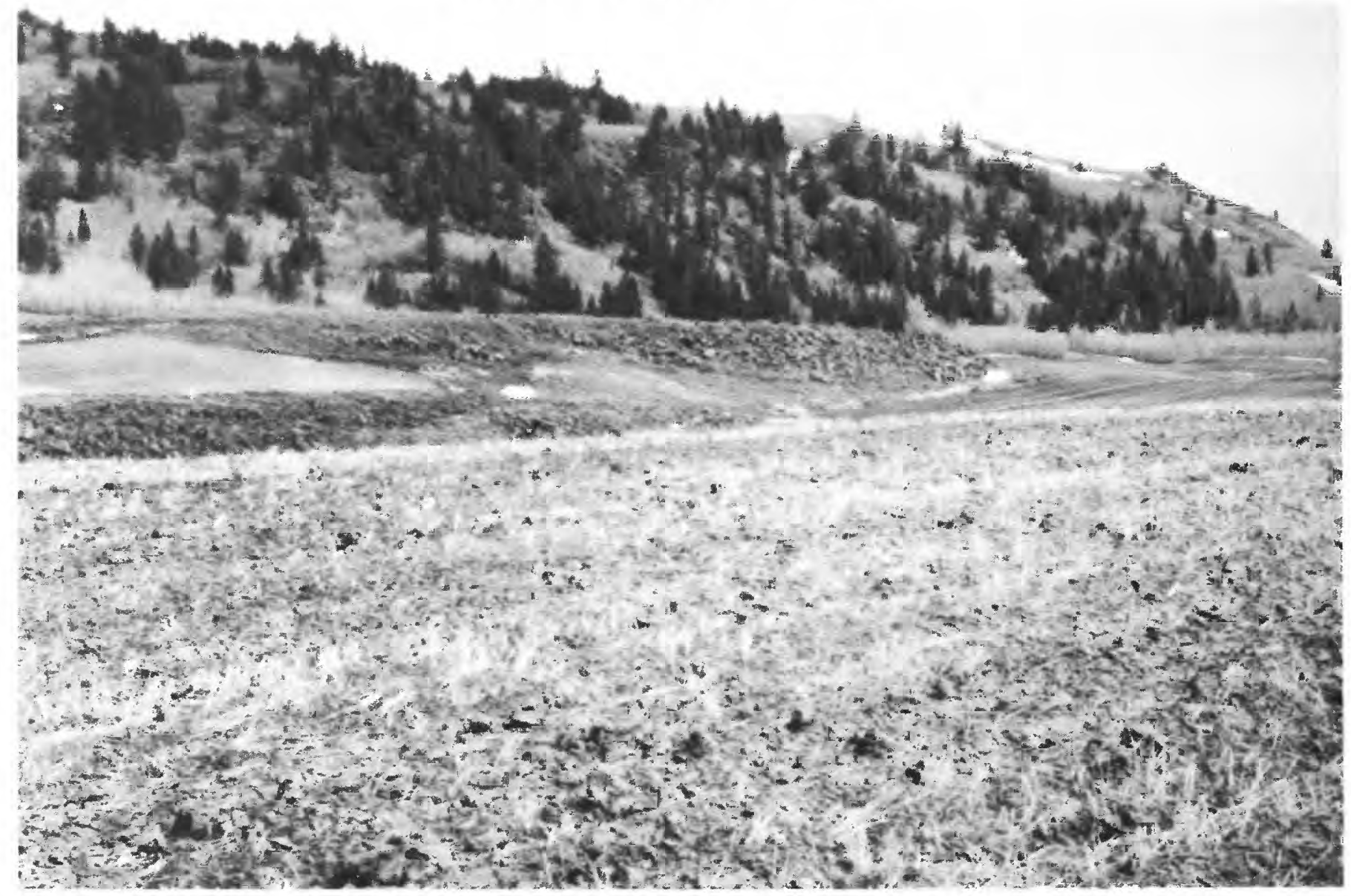

FigURE 4.-Diverse rocks and soils characteristic of the area north of Soda Springs, Idaho. Loess agricultural soils (foreground) as well as soils derived from the weathering of basalt (middleground) and limestone (background) are common. Photographed May 18, 1975.

tions of the total variance in concentration that is associated with distance from the processing sites. The covariation between logarithms of element content in plant and soil samples among the sample locations along each of the transects was estimated by the product-moment correlation coefficient.

Figure 5 illustrates the types of relations between concentrations and distances that were observed along the transects upwind and downwind of the processing sites. Figure $5 A$ shows element concentration in a single sampling medium decreasing with increasing distance from the processing site along both upwind and downwind transects. The regressions that describe these relations are statistically significant at a probability level of 0.05 . This type of relation provides strong evidence that the elevated element concentrations in a sampling medium close to the processing site are related to emissions. We consider these relations to be "significant."

Figures $5 B$ and $5 C$ show element concentrations in a sampling medium decreasing significantly with in- creasing distance from a processing operation along only one transect; the other transect shows a nonsignificant increase or decrease in element concentration with distance. This distribution pattern is probably related to element emissions from the processing site and is considered "important."

Figures $5 D$ and $5 E$ show element concentrations increasing significantly with increasing distance from the processing site along one transect. An increase in concentration with distance does not describe accumulation of wind-related emissions from processing operations; therefore, these relations are "unimportant" in this study and probably are intrinsic to the natural environment.

\section{ESTIMATING ELEMENT BURDEN IN SOILS}

We estimated the approximate concentrations of elements added to the soil by phosphate-processing operations along transects showing statistically significant relations between element content in soil 
TABLE 2.-Analytical methods and their detection limits for element analysis in soil plants and soils

[Elements in plants determined on ash, except as indicated. LLD, lower limit of determination expressed in parts per million; AA, atomic-absorbtion spectroscopy; COL, colorimetric; FLU, fluorimetric; IF, induction furnace; NA, neutron activation; SIE, selective ion electrode; SQS, multielement semiquantitative spectrography; and XRF. X-ray fluorescence, (...), not determined]

\begin{tabular}{|c|c|c|c|c|}
\hline \multirow[b]{2}{*}{ Elements } & \multicolumn{2}{|l|}{$\begin{array}{l}\text { Plants } \\
\end{array}$} & \multicolumn{2}{|c|}{ Soils } \\
\hline & Method & LLD & Method & LL \\
\hline 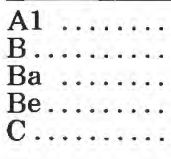 & $\begin{array}{l}\text { SQS } \\
\text { SQ. } \\
\text { SQS } \\
\text { SQS }\end{array} \ldots \ldots$ & $\begin{array}{r}100 \\
20 \\
2 \\
\ldots \\
\ldots\end{array}$ & $\begin{array}{l}\text { XRF } \ldots \\
\text { SQS } \\
\text { SQS }\end{array} \ldots .$. & $\begin{array}{r}10,000 \\
20 \\
2 \\
1 \\
500\end{array}$ \\
\hline $\begin{array}{l}\mathrm{Ca} \ldots \ldots \ldots \\
\mathrm{Cd} \ldots \ldots \ldots \\
\mathrm{Co} \ldots \ldots \\
\mathrm{Cr} \ldots \ldots \\
\mathrm{Cu} \\
\mathrm{Cu}\end{array}$ & $\begin{array}{l}\ldots \ldots \\
\text { AA } \\
\text { AA }\end{array} \ldots \ldots$ & $\begin{array}{l}\cdots .2 \\
1 \\
1 \\
1\end{array}$ & 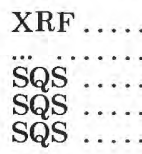 & $\begin{array}{c}1,000 \\
\ldots \\
3 \\
1 \\
1\end{array}$ \\
\hline 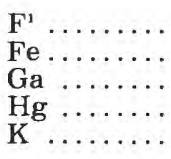 & 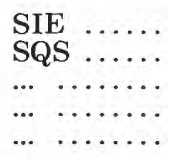 & $\begin{array}{c}1 \\
10 \\
\cdots \\
\cdots \\
\cdots\end{array}$ & $\begin{array}{l}\text { SIE } \ldots . \\
\text { XRF } \ldots . \\
\text { SQS } \ldots \\
\text { AA } \ldots \\
\text { XRF } \ldots\end{array}$ & $\begin{array}{r}10 \\
1,000 \\
5 \\
1,000^{.}\end{array}$ \\
\hline $\begin{array}{l}\mathrm{Li} \ldots \ldots \ldots \\
\mathrm{Mg} \ldots \ldots \\
\mathrm{Mn} \\
\mathrm{Mn} \\
\mathrm{Na} \\
\mathrm{Nb}\end{array}$ & $\begin{array}{l}\text { AA } \ldots \ldots \\
\text { SQS } \ldots \ldots \\
\text { SQS } \ldots \ldots \\
\text { AA } \ldots \ldots \\
\ldots \quad \ldots \ldots \\
\ldots\end{array}$ & $\begin{array}{r}4 \\
20 \\
1 \\
25 \\
\ldots\end{array}$ & $\begin{array}{l}\text { AA } \ldots \ldots \\
\text { XRF } \ldots \\
\text { XRF } \ldots \\
\text { AA } \ldots . \\
\text { SQS } \ldots\end{array}$ & $\begin{array}{c}5 \\
300 \\
1 \\
100 \\
10\end{array}$ \\
\hline $\begin{array}{l}\mathrm{Ni} \ldots \ldots \ldots \\
\mathrm{P} \ldots \ldots \\
\mathrm{Pb} \\
\mathbf{P b} \\
\mathrm{Rb} \\
\mathrm{Se}^{1} \ldots \ldots \ldots\end{array}$ & $\begin{array}{l}\text { SQS } \ldots \ldots \\
\text { COL } \ldots . . \\
\text { SQS } \ldots \ldots \\
\ldots \quad \ldots \ldots \\
\text { FLU } \ldots . . .\end{array}$ & $\begin{array}{r}5 \\
100 \\
10 \\
\cdots \\
.01\end{array}$ & $\begin{array}{l}\text { SQS } \ldots . \\
\text { XRF } \ldots . \\
\text { SQS } \ldots \\
\text { AA } \ldots . \\
\text { XRF } \ldots \\
\text { XR. }\end{array}$ & $\begin{array}{r}5 \\
2,000 \\
10 \\
1 \\
.1\end{array}$ \\
\hline $\begin{array}{l}\text { Si } \ldots \ldots \\
\text { Sn } \ldots \ldots \cdots \\
\text { Sr } \ldots \ldots \cdots \\
\text { Th } \ldots \ldots \\
\text { Ti } \ldots \ldots \\
\end{array}$ & 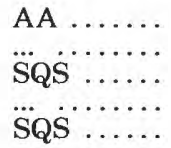 & $\begin{array}{r}100 \\
\ldots \\
5 \\
\ldots\end{array}$ & $\begin{array}{l}\text { XRF } \ldots . \\
\text { XRF } \ldots \\
\text { SQS } \ldots \\
\text { NA } \ldots \\
\text { XRF } \ldots \\
\text { XRF }\end{array}$ & $\begin{array}{r}10,000 \\
10 \\
5 \\
1 \\
2\end{array}$ \\
\hline $\begin{array}{l}\mathrm{U} \ldots \ldots \\
\mathrm{V}, \ldots \cdots \cdots \\
\mathrm{Y} \mathrm{b} \ldots \ldots \\
\mathrm{Zn} \ldots \ldots \\
\mathrm{Zr} \ldots \ldots\end{array}$ & $\begin{array}{l}\text { FLU } \ldots \ldots \\
\text { SQS } \ldots \ldots \\
\text { SQS } \ldots \ldots \\
\text { AA } \ldots . \\
\text { SQS } \ldots . \\
\end{array}$ & $\begin{array}{l}7^{.4} \\
1 \\
20 \\
10\end{array}$ & $\begin{array}{l}\text { NA } \ldots \ldots \\
\text { SQS } \ldots \ldots \\
\text { SQS } \ldots \\
\text { AA } \ldots . \\
\text { SQS } \ldots \\
\text { SQ }\end{array}$ & $\begin{array}{l}7^{.1} \\
10 \\
10 \\
10\end{array}$ \\
\hline
\end{tabular}

'Determined on dried plant material.

TABLE 3.-Detection ratios for selected elements in plants and soils at Pocatello and Soda Springs, Idaho, that have some values below the limits of determination

[Detection ratio, number of samples in which the element was found in measurable concentrations relative to the number of samples analyzed; leaders (..), element not included in the study of a given sampling medium]

\begin{tabular}{|c|c|c|c|c|c|}
\hline \multirow[b]{2}{*}{ Element } & \multicolumn{3}{|c|}{ Plants } & \multicolumn{2}{|c|}{ Soils } \\
\hline & $\begin{array}{c}\text { Big } \\
\text { sagebrush }\end{array}$ & Cheatgrass & $\begin{array}{l}\text { Bluebunch } \\
\text { wheatgrass }\end{array}$ & A horizon & $\mathrm{C}$ horizon \\
\hline $\mathrm{Be} . \ldots \ldots$ & & & & $49: 50$ & $22: 25$ \\
\hline$\overline{C d} \ldots \ldots$ & $48: 48$ & $19: 24$ & $26: 26$ & $50: 50$ & $25: 25$ \\
\hline Co...... & $48: 48$ & $21: 24$ & $21: 26$ & $50: 50$ & $22: 25$ \\
\hline $\mathrm{Hg} \ldots \ldots$ & & & & $50: 50$ & $23: 25$ \\
\hline Mn ..... & $48: 48$ & $24: 24$ & $26: 26$ & $50: 50$ & $24: 25$ \\
\hline Mo ..... & $48: 48$ & $23: 24$ & $26: 26$ & & \\
\hline $\mathrm{Nb} \ldots .$. & & & & 49:50 & $22: 25$ \\
\hline $\mathrm{Ni} \ldots \ldots$ & $48: 48$ & $16: 24$ & $21: 26$ & $50: 50$ & $25: 25$ \\
\hline $\mathrm{Pb} \ldots$. & $48: 48$ & $23: 24$ & $26: 26$ & $50: 50$ & $25: 25$ \\
\hline $\mathrm{Zr} \ldots \ldots$ & $48: 48$ & $21: 24$ & $22: 26$ & $\ldots$ & $\ldots$ \\
\hline
\end{tabular}

and distance. The estimation method was first used by Miesch and Huffman (1972) and was described in detail, as applied to this study, by Severson and Gough (1976). Using the processing site as the center of the circle of influence, the estimation is made by integrating the regression equation over a pie-shaped segment of the circle between two distances from the processing site.

\section{RESULTS OF ANALYSES SIGNIFICANCE OF EMISSION-RELATED ELEMENT DISTRIBUTIONS}

Tables 4, 5, 6, and 7 present results for all elements included in this study in both plants and soils along upwind and downwind transects at Pocatello and Soda Springs. The first two columns under a sampling medium contain estimates for the intercept $\left(b_{0}\right)$ and slope $\left(b_{1}\right)$ of the regression line for a specific constituent. A negative slope indicates that the element concentration tends to decrease with increasing distance from the processing site. Conversely, a positive slope indicates a tendency for the element concentration to increase with distance.

The third column of tables $4,5,6$, and 7 shows the probability that the slope of the regression line is actually zero. We consider as significant a probability of 0.05 . The fourth column in the tables presents the probability that the departure of the data from the linear regression model could have arisen by chance. Probabilities greater than the critical value of 0.05 indicate that the linear model is not appropriate at this level of significance.

The fifth column gives the coefficient of determination between element concentration in each sampling medium and distance. This value is a measure of the proportion of the total variation in the dependent variable, in this case, log element concentration, that is accounted for by the regression. For example, a value of 0.75 indicates that 75 percent of the observed variation in element concentration is accounted for simply by distance from the processing site.

The following classes were established to determine important relations between concentration of an element in a sampling medium and emissions from phosphate-processing operations: (1) "Significantly related," where negative regression slopes were significant at a probability of 0.05 for both downwind and upwind transects and a coefficient of determination equal to or greater than 0.50 was observed for one of the two transects; (2) "of probable importance," where a significant negative regression slope and a coefficient of determination equal to or greater than 0.50 were 


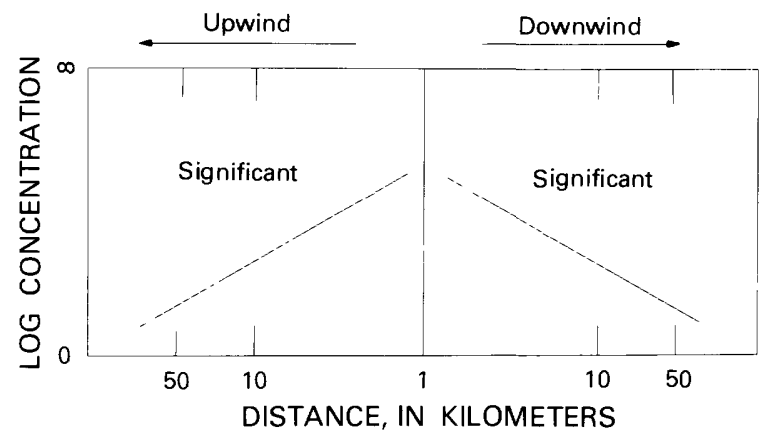

$A$
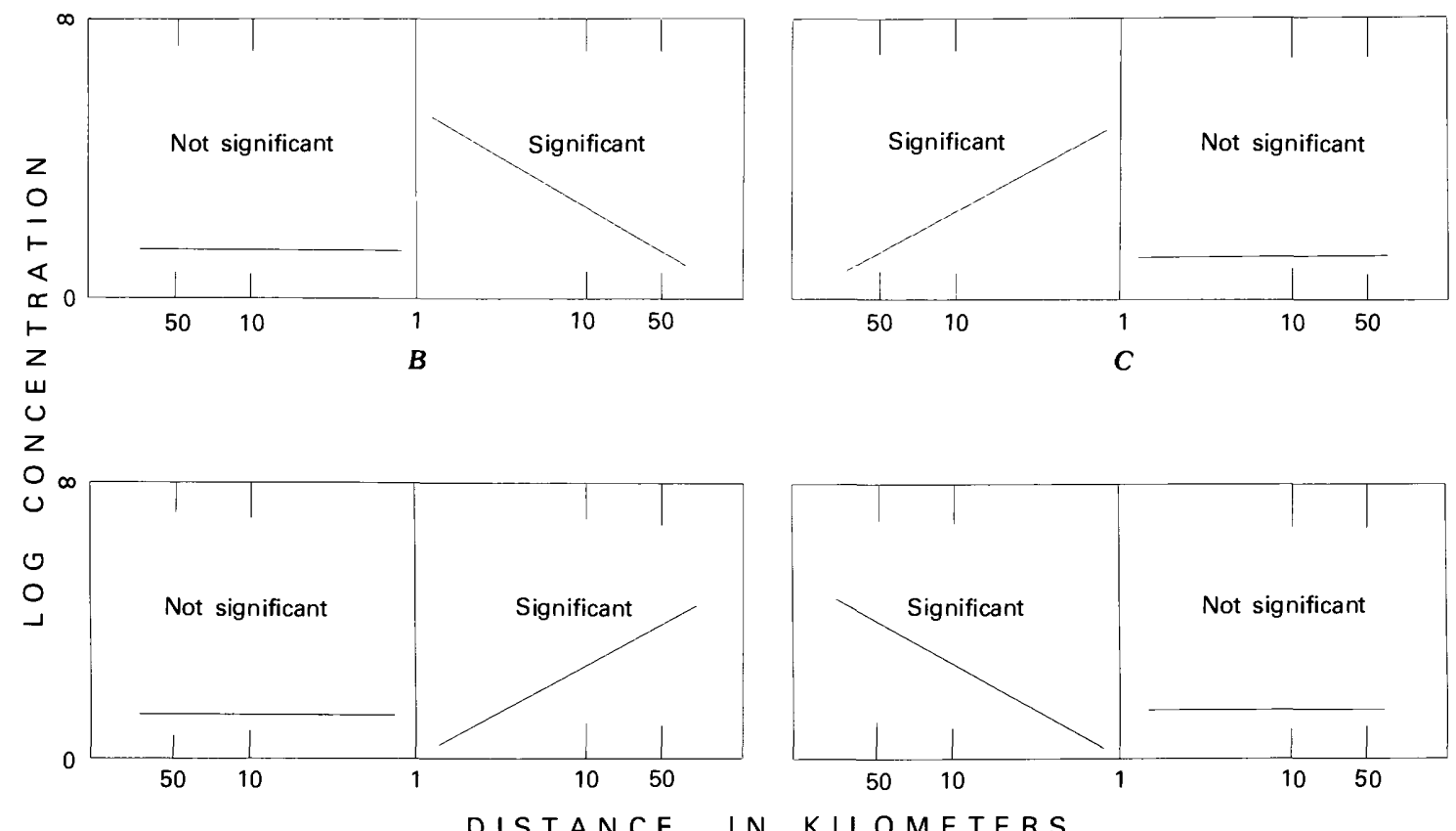

D

DISTANCE, IN KILOMETERS

E

FIGURE 5.-Typical relations between element concentrations in a sampling medium and distance of sampling site from phosphate processing operations. Trend line significance noted in figure. $A$, Important and related to phosphate processing. $B, C$, Important and probably related to phosphate processing. $D, E$, Not related to phosphate processing.

observed for one of the two transects. Also considered to be important in soils were a few elements for which the regression was significant at a probability level of 0.10 or whose coefficients of determination were less than 0.50 . The reasons for these exceptions will be discussed under "Element concentrations in soils."

\section{ELEMENT CONCENTRATIONS IN PLANTS}

Of the 23 elements listed in table 4, six in sagebrush at Pocatello (cadmium, chromium, fluorine, uranium, vanadium, and zinc) possessed significant negative regression slopes and acceptable coefficients of determination along both downwind and upwind transects. These elements, therefore, meet our criteria as being significantly related to phosphate-processing operations. Selenium probably should also be added to this list because the downwind regression slope was significant and the upwind slope was important at the 0.07 probability level. Two additional elements, nickel and phosphorus, are of probable importance because they possess significant negative slopes as well as acceptable coefficients of determination along only one-the downwind-transect.

Selenium is the only element in cheatgrass that qualified as being significantly related to phosphate operations near Pocatello. Chromium and vanadium may be considered important as they possessed significant negative slopes for either the downwind or up- 
ELEMENT EMISSIONS FROM PHOSPHATE-PROCESSING OPERATIONS IN SOUTHEASTERN IDAHO
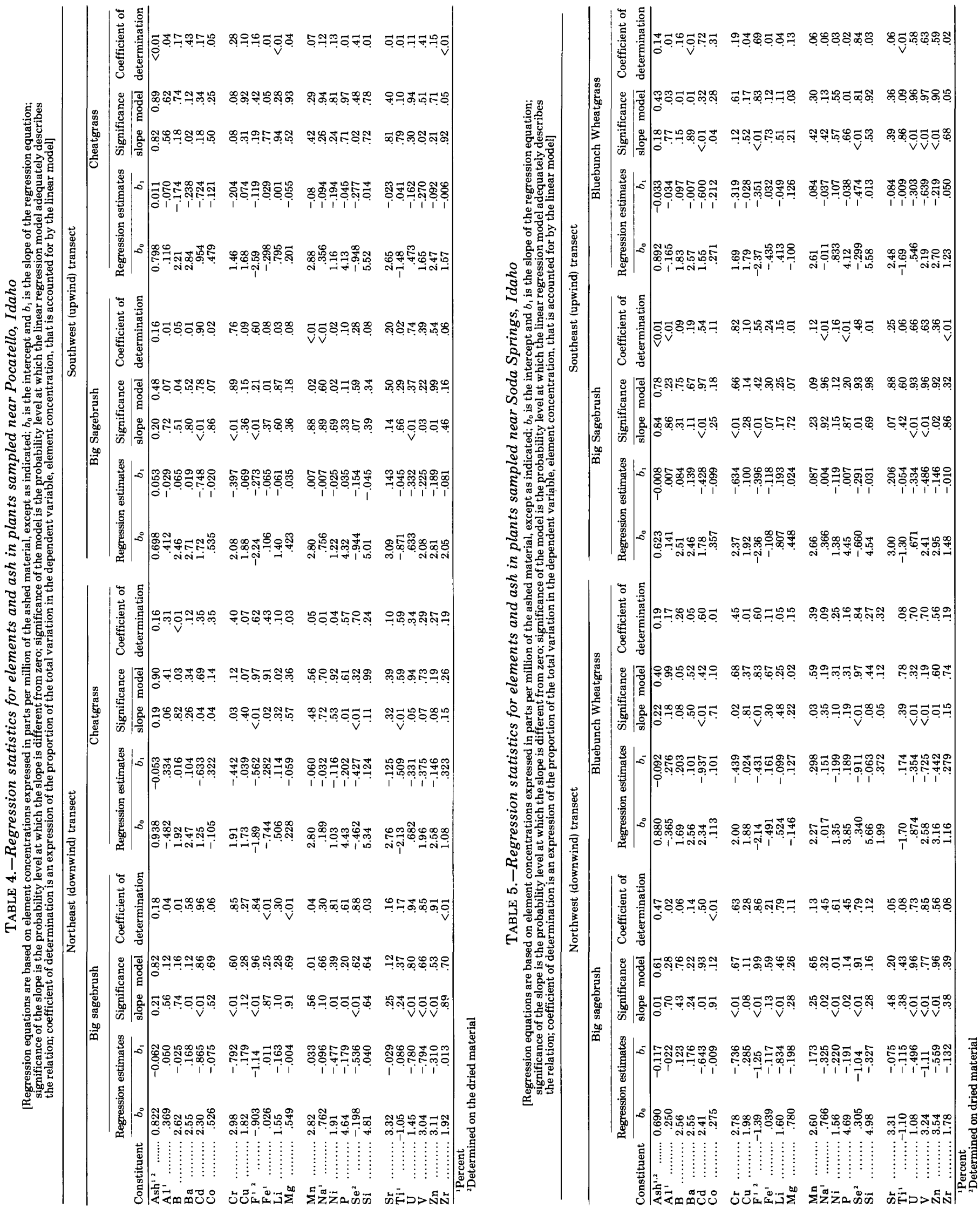
RESULTS OF ANALYSES

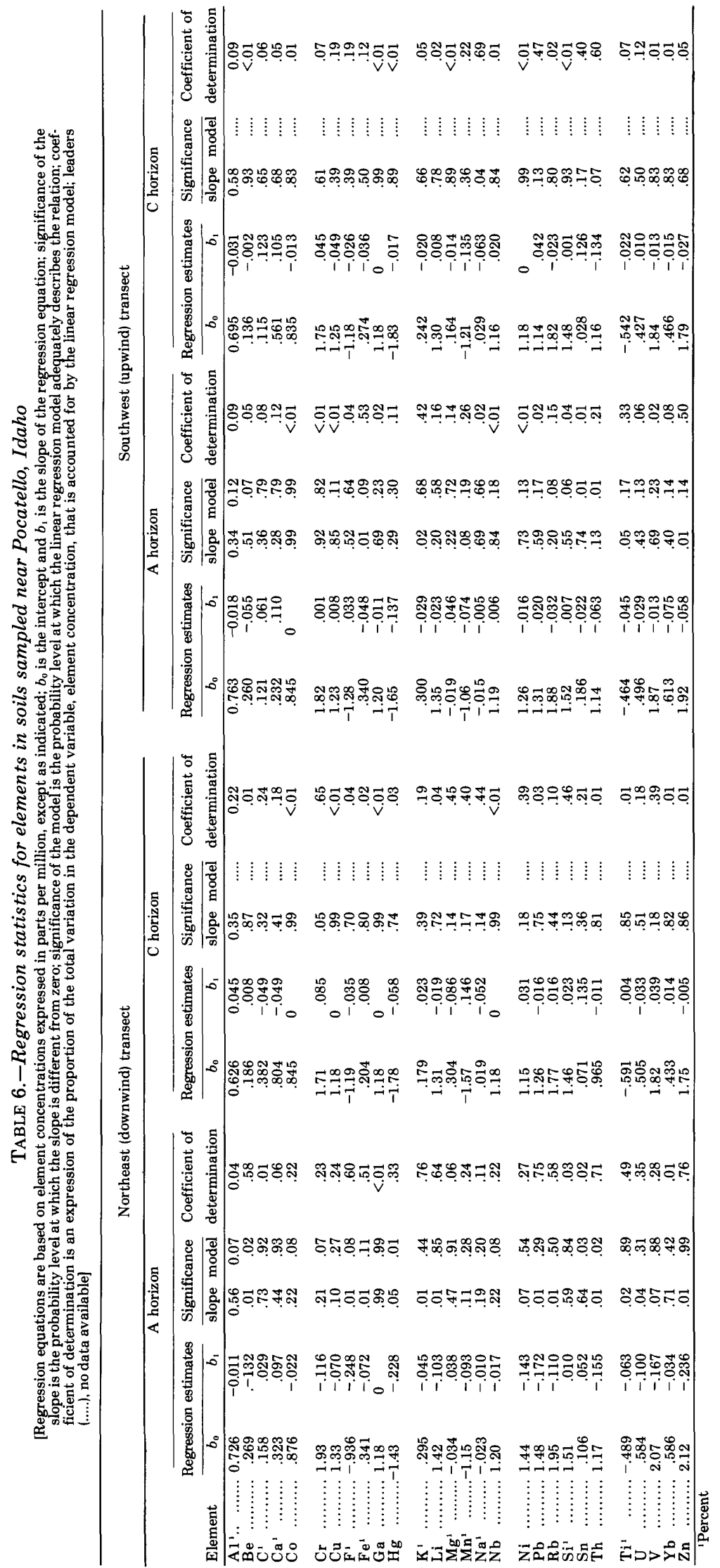




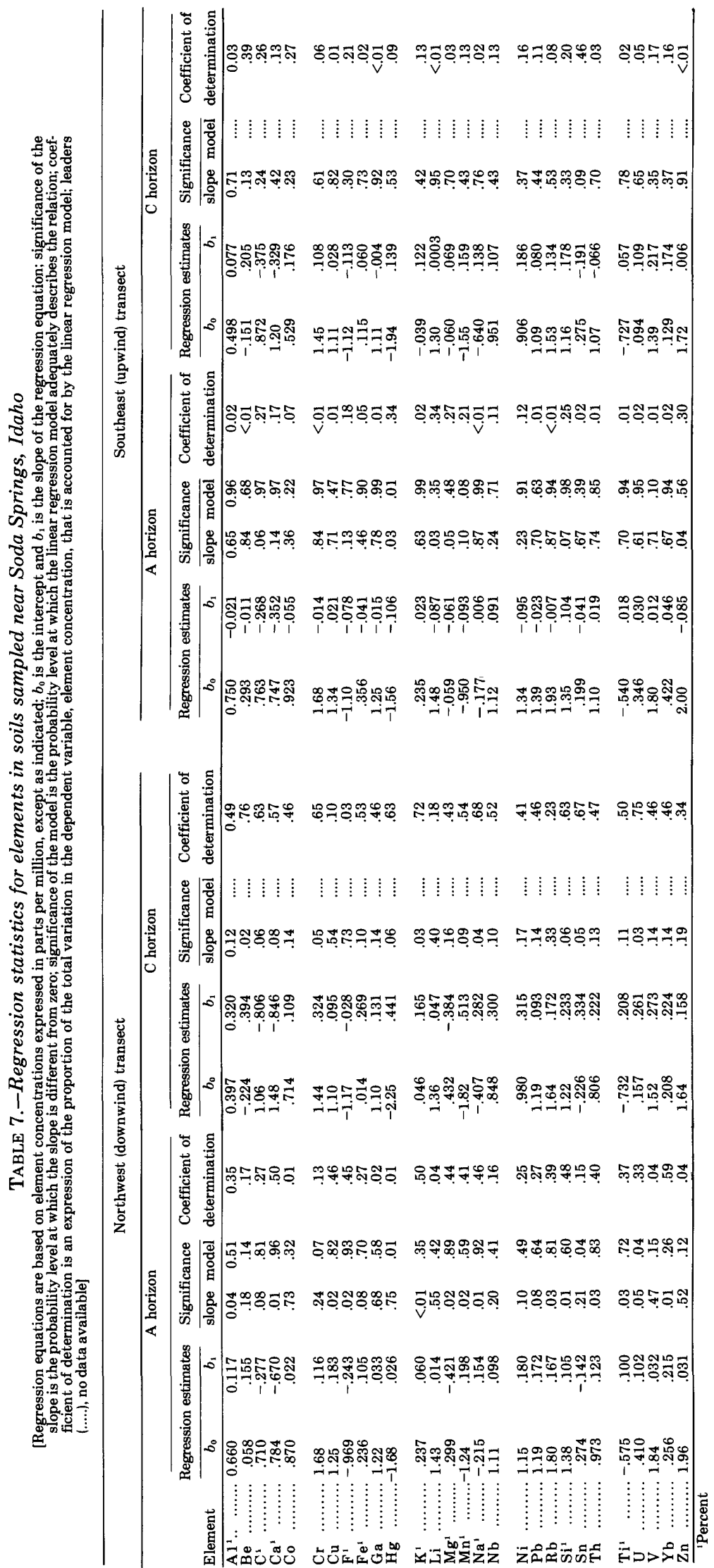


wind transect; they have, however, lower than acceptable coefficients of determination.

At Soda Springs (table 5), seven elements in sagebrush (cadmium, chromium, fluorine, selenium, uranium, vanadium, and zinc) are significantly related to phosphate-processing operations. Lithium and nickel show significant negative regression slopes and acceptable coefficients of determination along the downwind transect but not along the upwind transect; therefore, they are considered to be importantly associated with the processing operations. Phosphorus and sodium may also be important for they too show significance only along the downwind transect; however, they lack sufficiently high coefficients of determination.

In the bluebunch wheatgrass samples, cadmium, fluorine, selenium, uranium, vanadium, and zinc are significantly related to the phosphate-processing operations. The only other element of possible importance is chromium; however, along the upwind transect its negative regression slope is not significant, whereas along the downwind transect its negative slope is significant but its coefficient of determination is unacceptably low.

Overall, seven elements in plant tissue (cadmium, chromium, fluorine, selenium, uranium, vanadium, and zinc) are significantly associated with phosphateprocessing operations. Two additional elements, lithium and nickel, show frequent importance. Phosphorus and sodium may also reflect the impact of the phosphate operations, but unlike the first nine elements, which demonstrate importance along several transects and in a variety of plants sampled, these two show only questionable infrequent importance.

Although basically the same elements are involved in important relations at Pocatello and Soda Springs, there appear to be, in general, higher concentrations of these elements in the plants sampled at Soda Springs. This condition may be due either to differences in climate, phosphate-processing activity, element availability, and plant species or varieties, or to combinations of all these factors. Table 8 compares the relative concentrations of these elements to be expected in the plants at Pocatello and Soda Springs $3 \mathrm{~km}$ from the processing sites, according to the regression equations.

At Pocatello, where the downwind vector is greater than the upwind vector (fig. 1), many more downwind samples than upwind samples showed associations between elements in plants and the phosphate operations. At Soda Springs, however, the two main wind patterns, which are opposite but of about equal frequency, suggest that the effect of emissions on plants should reflect the somewhat stronger influence of the
TABLE 8.-Comparison of the estimated concentrations of selected trace elements in big sagebrush, cheatgrass, and bluebunch wheatgrass at distances of $3 \mathrm{~km}$ from phosphate-processing sites at Pocatello and Soda Springs, Idaho.

[Estimated concentration values (parts per million, in ash, except as indicated) were calculated using regression equations from tables 4 and 5 . Leaders(.....), relation between element concentration in plant material and distance was not significant. Values in parentheses indicate that the relation is of questionable significance]

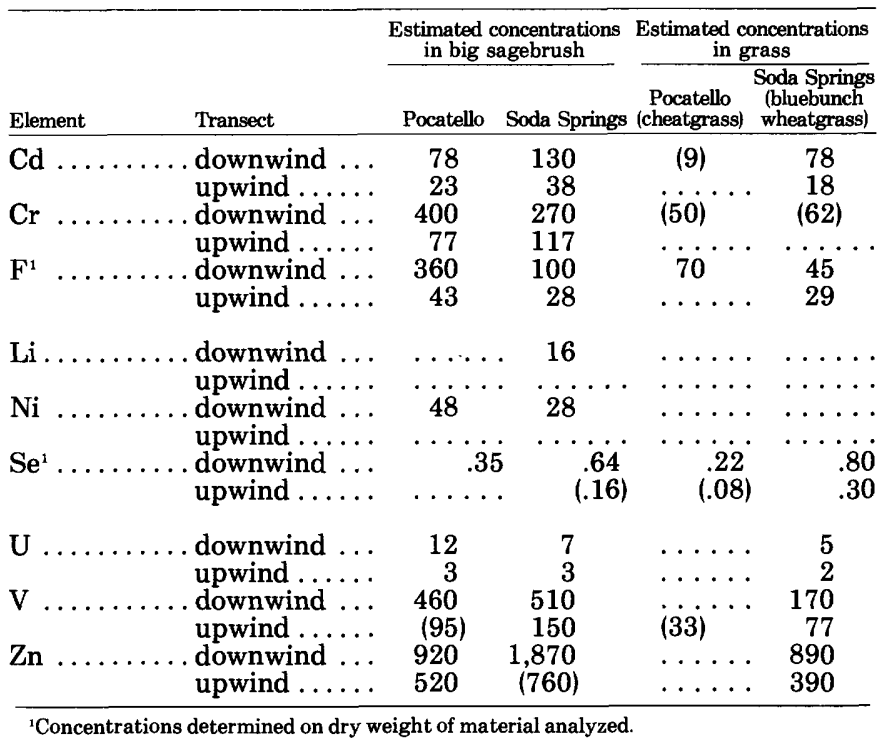

Concentrations determined on dry weight of material analyzed.

wind from the southeast. Table 5 shows that this is generally true, particularly for the chemical data on grasses. Still, concentrations of emission-related elements were generally higher downwind than upwind at both sites (table 8). Furthermore, the concentrations of cadmium, chromium, fluorine, uranium, vanadium, and zinc calculated for plants from the regression equations were unusually high $3 \mathrm{~km}$ from the processing operations, as compared with similar plant materials sampled in the Powder River Basin of Wyoming and Montana (Gough and Severson, 1976). Emissions from the phosphate operations, therefore, contributed substantial quantitites of certain trace elements to the plants that were sampled.

\section{ELEMENT CONCENTRATIONS IN SOILS}

Tables 6 and 7 present regression statistics for 28 elements in soils from the transects near Pocatello and Soda Springs, respectively. As discussed earlier, important relations between the concentrations of an element in soil and distance from processing sites are recognized as those that (1) show a statistically significant decrease in element concentration with increasing distance along at least one of the two transects, and (2) have a coefficient of determination of at least 0.50 .

Nine elements (beryllium, fluorine, iron, lead, lithium, potassium, rubidium, thorium, and zinc) in 
A-horizon soils downwind of the Pocatello operations (table 6) meet our criteria for being importantly related to processing-plant emissions. Six additional elements (copper, mercury, nickel, titanium, uranium, and vanadium) have regression lines whose slopes are significant at the 0.10 probability level and have coefficients of determination less than 0.50 . Of these 15 relations, departures from the linear model are nonsignificant at the 0.10 probability level for 4 elements (beryllium, fluorine, mercury, and thorium). Therefore, for 11 of the 15 relations, a more complicated model might better describe the relation between element concentration and distance. In A-horizon soils upwind of the Pocatello operations (table 6), only two elements (iron and zinc) meet our criteria for being importantly related to processing-plant emissions.

In A-horizon soils downwind of the Soda Springs operations, only calcium meets our criteria; upwind, there are no elements that we consider importantly related to phosphate-processing emissions. Most relations in A-horizon soils attributable to Pocatello processing-plant emissions occur in the transect which, according to the wind patterns shown in figure 1 , are downwind of the emission sources and hence reflect the typical primary path of airborne emissions in this area. The wind patterns at Soda Springs suggest that processing-plant emissions should appear in A-horizon soils along both transects. However, because of the soil variability at Soda Springs, element concentrations were not interpreted as being significantly related to distance from the emission sources.

Along all transects, only five elements in C-horizon soils meet our criteria for being important. We believe, however, that these element concentrations are not associated with processing operations because it is improbable that the precipitation in this area (about 50 $\mathrm{cm}$ annually) could have transported them through the soil profile to the $\mathrm{C}$ horizon in sufficient quantities since the processing factories began operations (about 50 years ago) to account for the statistically significant relations. Therefore, these relations are probably intrinsic to the natural environment (fig. 5).

Table 9 lists the estimated accumulations of those elements that presumably reflect processing-plant emissions in the soils near Pocatello, as well as the estimated average concentrations of selected elements in surface soils reported in the literature. The accumulation estimates are based on the linear regression model that describes the relationship between the logarithm of element concentration in soil and the logarithm of distance from the emission source. These element concentrations are total concentrations and may not represent in direct proportions the amounts of elements available to plants or subject to movement by percolating water. Table 9 includes nickel, uranium, and vanadium even though they do not meet our criteria for determining important relations. These elements are included because the slopes of their regression lines are significant between 0.05 and 0.10 probability levels and because they are demonsrated to be important in both sagebrush and cheatgrass along the same transect. Of the 12 elements in table 9, we consider fluorine, vanadium, and zinc to be present in unusually large amounts in the upper $5 \mathrm{~cm}$ of soil close to the processing plants.

\section{CORESPONDENCE BETWEEN ELEMENTS IN PLANTS AND SOILS}

Table 10 indicates for each transect the correlations between element concentrations in plants and total element concentrations in A-horizon soils and their levels of significance. Eleven elements (chromium, copper, fluorine, iron, lead, lithium, magnesium, nickel, uranium, vanadium, and zinc) showed correlations that are significant at the 0.10 probability level between soil and at least one plant species along at least one sample transect. A significant correlation may reflect a sensitive plant response to soil variation or direct introduction of airborne emissions to both plant and soil, or both.

Iron, lithium, magnesium, and lead showed significant correlations between soil and sagebrush but not between soil and grasses at both Pocatello and Soda Springs. However, the correlations were observed for the upwind transects only (table 9), and it is unlikely, therefore, that these relations reflect emissions from processing operations. Also, it is not possible to generalize that the concentrations of any of these elements in plants are due entirely to extraction of the elements from the soils because there are no consistent correlations for any single element among all transects.

We have discussed elsewhere the prediction of element concentrations in either plants or soils by using correlations between the fluorine and zinc concentrations in plants and the total concentrations of elements in soil along the downwind transect at Pocatello (Severson and Gough, 1976). We also discussed the difficulty of using such relations for prediction purposes at Soda Springs (Gough and Severson, 1976).

Other investigators have also reported the general lack of relation between element concentrations in plant ash and the total element concentration in soil. Shacklette, Sauer, and Miesch (1970) noted that the correlations between element concentrations in the ash of parts of trees or garden vegetables and the total ele- 
TABLE 9.-Estimated element concentrations in surface soils northeast (downwind) of phosphateprocessing sites near Pocatello, Idaho, and average concentration of elements in soils as reported in the literature

[Element concentrations (in ppm) between selected distances (in $\mathrm{km}$ ) are calculated by intergration of prediction equations using the appropriate regression estimates for slope and intercept in table 6; estimates for background concentration represent the arithmetic means of element concentrations in surface soils sampled in this study 32 and $64 \mathrm{~km}$ northeast of Pocatello; percent variation explained is an estimate of the proportion of the total variation in element concentration along a transect that is accounted for by the regression; averages from the literature are arithmetic means and represent soil and surficial material from the conterminous United States; leaders (.....), no data availiable]

\begin{tabular}{|c|c|c|c|c|c|c|c|}
\hline \multirow[b]{3}{*}{ Element } & \multicolumn{6}{|c|}{ Present Study } & \multirow{3}{*}{$\begin{array}{c}\text { Other studies } \\
\text { (average } \\
\text { concentration }\end{array}$} \\
\hline & \multicolumn{4}{|c|}{$\begin{array}{l}\text { Estimated concentration between } \\
\text { selected distances }\end{array}$} & \multirow{2}{*}{$\begin{array}{l}\text { Estimated } \\
\text { background }\end{array}$} & \multirow{2}{*}{$\begin{array}{c}\text { Percent variation } \\
\text { explained }\end{array}$} & \\
\hline & $1-2 \mathrm{~km}$ & $2-4 \mathrm{~km}$ & $4-16 \mathrm{~km}$ & $16-64 \mathrm{~km}$ & & & \\
\hline 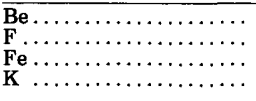 & $\begin{array}{r}1.8 \\
1,040 \\
21,300 \\
19,300\end{array}$ & $\begin{array}{r}1.6 \\
880 \\
20,200 \\
18,600\end{array}$ & $\begin{array}{r}1.4 \\
650 \\
18,500 \\
17,700\end{array}$ & $\begin{array}{r}1.1 \\
460 \\
16,800 \\
16,600\end{array}$ & $\begin{array}{r}1.1 \\
480 \\
16,800 \\
16,700\end{array}$ & $\begin{array}{l}58.1 \\
59.9 \\
51.0 \\
76.3\end{array}$ & $\begin{array}{r}1 \\
400 \\
25,000 \\
23,000\end{array}$ \\
\hline $\begin{array}{l}\mathrm{Li} \\
\mathrm{Ni} \\
\mathrm{Ni} \\
\mathrm{Pb} \\
\mathrm{Rb}\end{array}$ & $\begin{array}{l}25 \\
26 \\
28 \\
86\end{array}$ & $\begin{array}{l}23 \\
24 \\
25 \\
80\end{array}$ & $\begin{array}{l}20 \\
20 \\
20 \\
69\end{array}$ & $\begin{array}{l}18 \\
16 \\
16 \\
60\end{array}$ & $\begin{array}{l}18 \\
19 \\
16 \\
61\end{array}$ & $\begin{array}{l}64.4 \\
27.4 \\
75.2 \\
57.9\end{array}$ & $\begin{array}{l}25 \\
20 \\
20 \\
\ldots . .\end{array}$ \\
\hline $\begin{array}{l}\mathrm{Th}, \ldots \ldots \ldots \ldots \ldots \ldots \ldots \ldots \\
\mathrm{U} \\
\mathrm{V} \\
\mathrm{V} \\
\mathrm{Zn}\end{array}$ & $\begin{array}{r}13.9 \\
3.4 \\
110 \\
120\end{array}$ & $\begin{array}{r}12.5 \\
3.2 \\
98 \\
102\end{array}$ & $\begin{array}{l}10.3 \\
2.8 \\
82 \\
76\end{array}$ & $\begin{array}{l}8.3 \\
2.4 \\
63 \\
55\end{array}$ & $\begin{array}{l}8.3 \\
2.8 \\
78 \\
58\end{array}$ & $\begin{array}{l}70.9 \\
35.4 \\
28.1 \\
76.3\end{array}$ & $\begin{array}{l}\ldots . . \\
7 \ldots . \\
54 \\
54\end{array}$ \\
\hline
\end{tabular}

'Shacklette, Boerngen, Cahill, and Rahill (1973); Shacklette, Boerngen, and Keith (1974); Shacklette, Boerngen, and Turner (1971); Shacklette. Hamilton, Boerngen, and Bowles (1971).

TABLE 10.-Correlations between element concentrations in plants and in A-horizon soils along transects beginning near phosphateprocessing sites at Pocatello and Soda Springs, Idaho

[ $r$, product-moment correlation coefficient between logarithms of concentration; $N$, number of sample pairs; **, *, indicate significance of the correlation at the 0.01 and 0.05 probability levels respectively; (...), no data availiable]

\begin{tabular}{|c|c|c|c|c|c|c|c|c|c|c|c|c|c|c|c|c|}
\hline \multirow[b]{4}{*}{ Element } & \multicolumn{8}{|c|}{ Pocatello } & \multicolumn{8}{|c|}{ Soda Springs } \\
\hline & \multicolumn{4}{|c|}{ Northeast (downwind) transect } & \multicolumn{4}{|c|}{ Southwest (upwind) transect } & \multicolumn{4}{|c|}{ Northwest (downwind) transect } & \multicolumn{4}{|c|}{ Southeast (upwind) transect } \\
\hline & \multicolumn{2}{|c|}{ Big sagebrush } & \multicolumn{2}{|c|}{ Cheatgrass } & \multicolumn{2}{|c|}{ Big sagebrush } & \multicolumn{2}{|c|}{ Cheatgrass } & \multicolumn{2}{|c|}{ Big sagebrush } & \multicolumn{2}{|c|}{$\begin{array}{l}\text { Bluebunch } \\
\text { wheatgrass }\end{array}$} & \multicolumn{2}{|c|}{ Big sagebrush } & \multicolumn{2}{|c|}{$\begin{array}{l}\text { Bluebunch } \\
\text { wheatgrass }\end{array}$} \\
\hline & $r$ & $N$ & $r$ & $N$ & $r$ & $N$ & $r$ & $N$ & $r$ & $N$ & $r$ & $N$ & $r$ & $N$ & $r$ & $N$ \\
\hline$\overline{\mathrm{Al}} \ldots$ & 0.03 & 5 & -0.37 & 6 & 0.39 & 6 & 0.10 & 6 & 0.48 & 6 & -0.25 & 6 & 0.74 & 7 & 0.73 & 7 \\
\hline Co....... & 0.00 & $\ldots$ & & ... & & & & ... & $\begin{array}{r}0.40 \\
-.34\end{array}$ & 6 & -.25 & 6 & $\begin{array}{r}.14 \\
.30\end{array}$ & 7 & .64 & 7 \\
\hline $\mathrm{Cr} \ldots \ldots$ &.$\ddot{85}$ & $\dddot{5}$ &.$\ddot{76}$ & $\dddot{6}$ &.$\ddot{13}$ & $\dddot{6}$ &.$- \ddot{5}$ & $\dddot{6}$ & $-.85 *$ & 6 & $-.83 *$ & 6 & -.53 & 7 & -.04 & 7 \\
\hline $\mathrm{Cu}$. & -.46 & 5 & .32 & 6 & $0^{.10}$ & $\begin{array}{l}0 \\
6\end{array}$ & $0^{.00}$ & $\begin{array}{l}0 \\
6\end{array}$ & $.89 *$ & 6 & $\begin{array}{l}.00 \\
-.52\end{array}$ & 6 & -.05 & 7 & .16 & 7 \\
\hline$F \ldots \ldots$ & $.95 *$ & 5 & $.99 * *$ & 6 & -.29 & 6 & -.33 & 6 & $-.84^{*}$ & 6 & $-.84 *$ & 6 & .10 & 7 & .17 & 7 \\
\hline $\mathrm{Fe} \ldots \ldots$ & -.24 & 5 & -.15 & 6 & .67 & 6 & -.13 & 6 & -.13 & 6 & .10 & 6 & $-.79 *$ & 7 & .64 & 7 \\
\hline $\mathrm{Li} \ldots \ldots$ & .47 & 5 & -.11 & 6 & $.89 *$ & 6 & -.42 & 6 & -.51 & 6 & .32 & 6 & .12 & 7 & .58 & 7 \\
\hline $\mathbf{M g} \ldots \ldots$ & -.09 & 5 & .61 & 6 & .24 & 6 & & $\ldots$ & .23 & 6 & -.41 & 6 & $.83^{*}$ & 7 & -.12 & 7 \\
\hline Mn ..... & -.03 & 5 & .41 & 6 & $\ldots$ & ... & -.16 & $\dddot{6}$ & .52 & 6 & .09 & 6 & .18 & 7 & .14 & 7 \\
\hline $\mathrm{Na} \ldots .$. & .03 & 5 & .46 & 6 & -.19 & 6 & -.12 & 6 & -.72 & 6 & -.01 & 6 & .67 & 7 & .21 & 7 \\
\hline $\mathrm{Ni} \ldots \ldots$ & .78 & 5 & .59 & 6 & $.94^{* *}$ & 6 & .52 & 6 & -.70 & 6 & .03 & 6 & .29 & 7 & .34 & 7 \\
\hline $\mathrm{Pb} \ldots \ldots$ & .13 & 5 & -.48 & 6 & $-.87^{*}$ & 6 & -.62 & 6 & -.03 & 6 & -.23 & 6 & -.14 & 7 & .17 & 7 \\
\hline Si $\ldots \ldots$ & -.39 & 5 & .48 & 6 & .60 & 6 & -.22 & 6 & .07 & 6 & -.25 & 6 & .17 & 7 & -.18 & 7 \\
\hline $\mathrm{Ti} \ldots$ & -.19 & 5 & -.39 & 6 & .75 & 6 & 0 & 6 & .22 & 6 & .15 & 6 & -.38 & 7 & .67 & 7 \\
\hline $\mathrm{U} \quad \ldots$ & $.93^{*}$ & 5 & $.86^{*}$ & 6 & .49 & 6 & .14 & 6 & -.79 & 6 & -.58 & 6 & -.30 & 7 & -.29 & 7 \\
\hline$V \ldots \ldots$ & .80 & 5 & .76 & 6 & .40 & 6 & -.09 & 6 & -.57 & 6 & -.18 & 6 & .03 & 7 & .06 & 7 \\
\hline $\mathrm{Zn} \ldots \ldots$ & $.96 * *$ & 5 & $.87 *$ & 6 & .77 & 6 & .80 & 6 & -.80 & 6 & -.59 & 6 & $.82^{*}$ & 7 & .34 & 7 \\
\hline
\end{tabular}

ment concentration in soil in a study in Georgia were inconsistent, were not reproducible, and probably resulted largely from chance. J. A. Erdman (botanist, U.S. Geol. Survey, oral commun., 1976) reported no good correspondence between chemistry of plant ash and total element concentration in soil for 29 elements in sagebrush and soil in the Powder River Basin of Wyoming and Montana.

This lack of correspondence between soil and plant chemistry is not surprising. Mitchell $(1964$, p. 342) reported that no two plant species growing in the same soil will necessarily extract the same quantity of an element. Furthermore, he reported that the element uptake by a single plant species varies if the plant is grown in different soils. Soil properties, such as $\mathrm{pH}$, organic-matter content, microbial population, oxidation-reduction potential, and water regime, certainly affect the element availability in soil and influence the absorption of elements by plants. In addition, the gross composition of the soil, the total concen- 
tration of the element of interest, its concentration relative to that of other elements, and its compositional form or forms also affect the amount of the element available to, and absorbed by, a plant species.

\section{ENVIRONMENTAL IMPLICATIONS GENERAL IMPACT OF ELEMENT EMISSIONS ON HEALTH}

Having assessed the elements contributed to selected plants and soils by emissions from phosphateprocessing operations and having delineated zones of maximum influence along selected transects, we now apply the results of this study to an analysis of the potential, but unproven, effects of the emitted elements on the present and future health of plants and animals within the zones of influence. Such an application must be approached with caution because little is known about the biologic responses to chronic chemical insult at the molecular level. In the following discussion, we speculate on a few potential health effects, keeping in mind the constraints originally imposed on the study by its design and major purpose. Table 11 summarizes information from the literature on the toxicity of elements, determined to be important in this study, on plant and animal health. We did not attempt to review the literature relative to human health.

A very important aspect of element toxicity is the interaction between the elements. Bowen (1966) listed six basic mechanisms of toxic action of elements within the cell; these are their ability to (1) inactivate enzymes, particularly by the more electronegative metals such as copper, mercury, and silver (these metals are highly reactive with the amino, imino, and sulphydryl groups in proteins and thereby render them inactive); (2) function as antimetabolites (arsenate and chlorate substitute for phosphate and nitrate, respectively); (3) form stable precipitates or chelates with essential metabolites (aluminum, beryllium, scandium, titanium, yttrium, and zirconium react with phosphate); (4) catalyze the decomposition of ATP (adenosine triphosphate); (5) combine with the cell membrane and thereby affect its permeability (gold, cadmium, copper, mercury, lead, and free halogens affect the transport of sodium, potassium, and organic molecules across membranes); and (6) replace structurally or electrochemically important elements

TABLE 11.-Suspected and known toxic effects of selected elements in plants and animals

\begin{tabular}{|c|c|c|c|c|}
\hline \multirow[b]{2}{*}{ Element } & \multicolumn{2}{|c|}{ On plants } & \multicolumn{2}{|c|}{ On animals } \\
\hline & Under natural conditions & Under man-induced conditions & Under natural dietary conditions & Under man-induced dietary conditions \\
\hline Cadmium .. & $\begin{array}{l}\text { Not demonstrated (Fleischer and } \\
\text { others, 1974). }\end{array}$ & $\begin{array}{l}\text { Moderate (Brooks, 1972). } 3 \text { ppm Cd in plant } \\
\text { tissue caused growth depression (no spe- } \\
\text { cies mentioned)' (Allaway, 1968). Growth } \\
\text { reduction when nutrient solution con- } \\
\text { tained } 0.2 \mathrm{ppm}-\text { beets, beans, turnips; } \\
1 \text { ppm-corn, lettuce; } 5 \text { ppm-tomato, } \\
\text { barley; } 9 \text { ppm-cabbage (Page and others, } \\
1972 \text { ). }\end{array}$ & $\begin{array}{l}\text { Not demonstrated (Fleischer and } \\
\text { others, 1974). }\end{array}$ & $\begin{array}{l}\text { Moderate to high (Allaway, 1968). Suspect- } \\
\text { ed of killing a horse-80 ppm Cd in liver, } \\
410 \mathrm{ppm} \mathrm{Cd} \mathrm{in} \mathrm{Kidney} \mathrm{(Lewis,} \mathrm{1972).} \\
30-60 \mathrm{ppm} \text { Cd in diet of sheep for 191 } \\
\text { days reduced growth and feed intake } \\
\text { (Doyle and others, 1972). } 45 \mathrm{ppm} \text { Cd in } \\
\text { diet of rats for } 6 \text { months caused slight } \\
\text { toxic symptoms (Underwood, 1971). }\end{array}$ \\
\hline Chromium . & $\begin{array}{l}\text { Probable. Growth of only certain } \\
\text { species on serpentine soils } \\
\text { (Brooks, 1972); excessive Ni, } \\
\text { unfavorable Mg:Ca ratios, and } \\
\text { deficiency of Mo may be limit- } \\
\text { ing factors (Vanselow, 1966). } \\
\text { Soil from "poison spots" in Ore- } \\
\text { gon contain as much as 2-3 per- } \\
\text { cent chromic oxide (McMurtrey } \\
\text { and Robinson, 1938). }\end{array}$ & $\begin{array}{l}\text { Severe (Brooks, 1972), moderate (Allaway, } \\
1968 \text { ). Cr in the form of chromates partic- } \\
\text { ularly toxic (McMurtrey and Robinson, } \\
1938 \text { ). } 1,370-2,740 \text { ppm } \mathrm{Cr} \text { in soil caused } \\
\text { chlorosis in citrus; } 10-15 \text { ppm Cr (as } \\
\mathrm{K}_{2} \mathrm{Cr}_{2} \mathrm{O}_{7} \text { ) in nutrient solution toxic to bar- } \\
\text { ley (Mertz, 1974a). 4-8 ppm } \mathrm{Cr} \text { in leaves } \\
\text { of corn was toxic }{ }^{2} \text { (Soane and Saunder, } \\
\text { 1959). }\end{array}$ & Not demonstrated (Underwood, 1971). & $\begin{array}{l}\text { Of little significance (Mertz, 1974a). Toxic- } \\
\text { ity low (Allaway, 1968). 30-40 mg/kg } \\
\text { (ppm) zinc chromate lethal to calves with- } \\
\text { in } 1 \text { month, about } 20 \text { times that amount } \\
\text { lethal to cows; } 30 \mathrm{ppm} \mathrm{Cr} \text { in liver diag- } \\
\text { nostic of Cr toxicity. Potentially carcin- } \\
\text { ogenic (Bowen, } 1966 \text { ). } 50 \mathrm{ppm} \text { in diet as- } \\
\text { sociated with growth depression in exper- } \\
\text { imental animals (Underwood, 1971). }\end{array}$ \\
\hline Fluorine ... & $\begin{array}{l}\text { Unusual. Plants growing in acid } \\
\text { soils have accumulated toxic } \\
\text { levels of } F \text { (Allaway, 1968). }\end{array}$ & $\begin{array}{l}\text { Moderate when absorbed through the roots } \\
\text { (Bowen, 1966). } 30-300 \text { ppm } F \text { in plant } \\
\text { tissue generally reduced growth (depend- } \\
\text { ing on species and conditions) } ; 200 \text { ppm } \\
F \text { in mature leaves of citrus associated } \\
\text { with reductions in yield and growth; } \\
<200 \text { ppm } F \text { in tops of alfalfa caused no } \\
\text { toxic effects }{ }^{4} \text { (National Research Council, } \\
\text { 1971). }\end{array}$ & $\begin{array}{l}\text { Unusual. Lethal fluorosis of sheep and } \\
\text { other livestock reported following } \\
\text { volcanic eruption on Iceland (Thor- } \\
\text { arinsson, 1970). Endemic fluorosis } \\
\text { reported from areas where drinking } \\
\text { water contained unusually high F } \\
\text { (Underwood, 1971). }\end{array}$ & $\begin{array}{l}\text { Moderate (Allaway, 1968). Ambient air pri- } \\
\text { mary source of } F \text { in forage as F not read- } \\
\text { ily absorbed through roots (National Re- } \\
\text { search Council, 1971). Concentration of F } \\
\text { in dietary dry matter above which nor- } \\
\text { mal performance may be affected: beef } \\
\text { or dairy heifers, } 40 \text { ppm; horses, } 60 \text { ppm; } \\
\text { finishing cattle, } 100 \mathrm{ppm} \text {; broiler chick- } \\
\text { ens, } 300 \mathrm{ppm} \text {; breeding hens, } 400 \mathrm{ppm} \text {; } \\
\text { turkeys, 400 ppm (National Research } \\
\text { Council, 1974). }\end{array}$ \\
\hline
\end{tabular}


TABLE 11.-Suspected and known toxic effects of selected elements in plants and animals-Continued

\begin{tabular}{lcc}
\hline Element & On plants & \multicolumn{1}{c}{ Under man-induced conditions } \\
\cline { 2 - 3 } Lithium .... Unusual. Citrus appears sensitive & $\begin{array}{l}\text { Unatural conditions } \\
\text { to an Li concentration in soil of } \\
\text { about } 12 \text { ppm (Mertz, 1974b). }\end{array}$ & $\begin{array}{c}\text { Slight (Brooks, 1972). Many crops suscep- } \\
\text { tible to "injury" when Li is applied to soil } \\
\text { in form of soluble salts (McMurtrey and } \\
\text { Robinson, 1938). Many plants tolerant of }\end{array}$ \\
"high" Li levels (Mertz, 1974b). Toxic to \\
citrus when Li concentration in soil (as \\
$\left.\mathrm{Li}_{2} \mathrm{SO}_{4}\right)$ was 2-5 ppm and in leaves 140- \\
$220 \mathrm{ppm}^{2}$ (Aldrich and others, 1951).
\end{tabular}

Nickel .... Probable. Growth of only certain species on serpentine soils (Brooks, 1972); excessive $\mathrm{Cr}$ unfavorable Mg:Ca ratios, and deficiency of Mo may be limiting factors (Vanselow, 1966). Apetalous forms of anemone growing over nickel silicate deposit (Malyuga, 1964).

Selenium... Probable. Toxic to most plants (McMurtrey and Robinson, 1938). Only certain species grow on seleniferous soils (Cannon, 1971).
Uranium ... Probable. Long-term low-level natural radiation from pitchblende outcrops suspected as cause of deformities in fruit of bog bilberry, and of flower color varia. tion in fireweed (Shacklette, $1962,1964)$. Variation in flow. ers of princesplume growing over carnotite (Cannon, 1960).

Vanadium . Unknown.

Zinc ....... Probably none (Allaway, 1968) Flower modifications in poppy growing in soils high in $\mathrm{Zn}$ (Malyuga, 1964). Chlorosis of plants growing in $\mathrm{Zn}$ peat underlain with sphalerite and dolomite (Cannon, 1955).
Severe (Brooks, 1972). Toxic to plant growth (McMurtrey and Robinson, 1938). Poisonous to plants even at relatively "low" concentrations; $40 \mathrm{ppm}$ in tomato toxic, 150 ppm stopped growth ${ }^{1}$ (Sauchelli, 1969). 12-246 ppm Ni in leaves of corn toxic, 14$34 \mathrm{ppm} \mathrm{Ni}$ in leaves of tobacco toxic ${ }^{2}$ (Soane and Saunder, 1959).

Moderate (Brooks, 1972). $700 \mathrm{ppm}$ Se in wheat caused no effects when sulfur content of plant high, $<250 \mathrm{ppm}$ Se caused chlorosis of leaves when sulfur content was low (Trelease and Beath, 1949). Chlorosis and dwarfing of gumweed when grown in seleniferous test plots (Cannon, 1964). Toxic at levels of $50-100 \mathrm{ppm}^{4}$ (Allaway, 1968). Ability to absorb Se highly variable among species (Ganje, 1966).

Moderate (Brooks, 1972). Abnormal flowers noted on princesplume grown in test plots having a radiation source (Cannon, 1960 ).

Moderate (Brooks, 1972). Stunting of plants grown in test plots treated with sodium vanadate (Cannon, 1960). With "very low" levels of $\mathrm{V}$ in nutrient solutions plant growth was depressed (Allaway, 1968). $>2 \mathrm{ppm} V$ in tops probably toxic to peas and soybeans ${ }^{2}$ (Pratt, 1966).

Moderate (Brooks, 1972). "Large" quantities in soil toxic to plants (McMurtrey and Robinson, 1938). Chlorosis of leaves of sweetpea, tomato, bluegrass, and violet when grown in nutrient solutions containing zinc acetate (Cannon, 1955). About $150 \mathrm{ppm} \mathrm{Zn}$ in leaves of corn, soy. beans, wheat, barley, and oats appeared to be toxic; about $200 \mathrm{ppm}$ in citrus leaves is toxic' (Sauchelli, 1969). $>50 \mathrm{ppm} \mathrm{Zn}$ in navy bean decreased yields ${ }^{1}$ (Melton and others, 1970). 2,000 ppm $\mathrm{Zn}$ in certain bryophytes produced no apparent toxic effects ${ }^{5}$ (Shacklette, 1965).
Probably none. Relatively nontoxic (Underwood, 1971), like $\mathrm{Zn}, \mathrm{Mn}$, and Cr.

Toxic effects by 3-5 ppm Se in forage produced in "animals" (Oldfield, 1974). $4 \mathrm{ppm}$ Se is tolerance limit in forage plants used for cattle and sheep (Sullivan and Garber, 1947, cited by Sauchelli, 1969). Water containing $0.5 \mathrm{ppm}$ Se potentially dangerous (Ganje, 1966).

Unknown, either from its chemical or radiation properties.

Unknown.

Probably none (Allaway, 1968).
Moderate to low (Allaway, 1968). $700 \mathrm{ppm}$ $\mathrm{Ni}$ in diet depressed growth of chicks; $1,600 \mathrm{ppm} \mathrm{Ni}$ depressed growth of young mice; $1,000 \mathrm{ppm} \mathrm{Ni}$ had no effect on rats or monkeys (Underwood, 1971). Potentially carcinogenic (Bowen, 1966).

High. >4-5 ppm Se in animal diets generally depressed growth rates (Allaway. 1968). Soils having $>0.5 \mathrm{ppm}$ Se regarded as potentially hazardous to livestock; $10-15 \mathrm{ppm}$ Se in diet of swine produced selenosis within 2-3 weeks (Underwood, 1971).

Unknown, either from its chemical or ra diation properties.
Moderate (Allaway, 1968). $>20-25$ ppm V in diet caused growth depression in chicks $25 \mathrm{ppm} \mathrm{V}$ in diet of rats was toxic, 50 ppm caused diarrhea and mortality; relative toxicity of five elements to rats when fed 25 ppm diets: As $<\mathrm{Mo}<\mathrm{Te}<\mathrm{Se}$ (Underwood, 1971).

Low (Allaway, 1968). $>1,000 \mathrm{ppm} \mathrm{Zn}$ in diet (as $\mathrm{ZnCO}_{4}$ ) of weanling pigs depressed growth and caused arthritis and internal hemorrhage; $4,000 \mathrm{ppm}$, mortality high; $1,000 \mathrm{ppm} \mathrm{Zn}$ in diet of lambs re duced gains, $900 \mathrm{ppm} \mathrm{Zn}$ in diet of feeder cattle reduced gains (Underwood, 1971).

\footnotetext{
${ }^{1}$ Concentrations assumed to be determined on the ashed material.

${ }^{2}$ Concentrations determined in the dried material.

${ }^{3}$ A. A. Case, clinical veterinarian, University of Missouri, written commun., 1977

${ }^{4}$ Concentrations assumed to be determined on the dried material.

${ }^{5}$ Concentrations determined on the ashed material.
} 
(lithium replaces sodium, cesium replaces potassium).

Figure 6 illustrates the major paths traveled by elements emitted into the air from phosphateprocessing operations. Soils and ground water are more stable reservoirs for these elements; however, the elements may be incorporated into animals and humans either directly through the air or by first passing into vegetation that is then consumed. In an agronomic system, the food chain terminates at the herbivore level (if humans as omnivores are not considered) and can result in the concentration of elements in animal tissue. If there is no physiological mechanism to eliminate these elements, acute or chronic pathological symptoms may develop. Relative toxicity, however, depends on many interrelated factors, which we will discuss shortly. Monitoring the concentration of these elements in forage plants is an important method of predicting the quality of animal health.

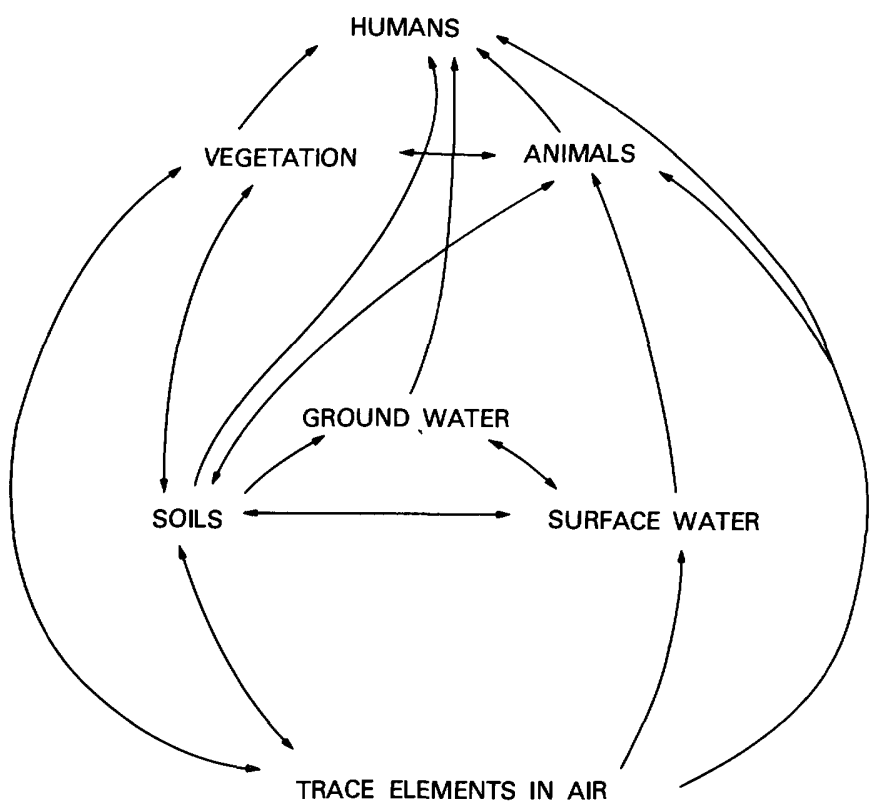

FIGURE 6.-Major pathways in the natural migration of trace elements from phosphate-processing emissions.

\section{EMISSION-RELATED SURFACE CONTAMINATION OF VEGETATION}

The influence of washing on the element concentration in vegetation was determined from a suite of washed and unwashed grasses. We collected 24 samples of bluebunch wheatgrass within a $100-\mathrm{m}$ radius $2 \mathrm{~km}$ downwind of the elemental-phosphorus plant at Soda Springs. We washed one-half of these samples, using the methods discussed earlier, and then submitted for analysis these samples, along with the transect study samples, in a randomized sequence.
Of the 24 elements reported from washed and unwashed grass in table 12, 13 occurred in significantly greater amounts (probability level $\leqslant 0.05$ ) in the unwashed samples than in the washed samples. Washing removed aluminum, boron, cadmium, chromium, fluorine, iron, lead, nickel, selenium, silver, titanium, uranium, and zirconium. Of these 13 elements, aluminum, iron, titanium, and zirconium may be more closely linked to local dust contamination than to the processing-site emissions. The remaining nine elements are known constituents of the local phosphate rock and probably reflect, in one form or another, the elemental-phosphorus operation; of these elements, the concentrations of cadmium, chromium, fluorine, nickel, selenium, and uranium were identified in this study as increasing in sagebrush and grasses toward the phosphate-processing operations. Fluorine and silver are of particular interest because the unwashed grass samples contained more than three times more fluorine and almost three times more silver than did the washed samples.

TABLE 12.-Chemistry of 24 washed and unwashed bluebunch wheatgrass samples collected $2 \mathrm{~km}$ downwind from an elementalphosphorus plant, Soda Springs, Idaho

[Values determined on plant ash, except as indicated. Values are in parts per million (ppm), except as indicated. Detection ratio is the number of samples having measurable property relative to the number of samples analyzed for that property; significance of $F$ values were determined using 1 and 11 degrees of freedom of the numerator and denominator mean square, respectively; ${ }^{*}$, significant $F$ value at the 0.05 probability level (critical value of 4.84):**, significant $F$ value at the 0.01 probability level (critical value of 9.65 ). The number of samples having a measurable amount of each constituent is the same as the number of samples analyzed for that constituent, except for $\mathrm{Ag}$, for which 22 samples had measurable amounts and $\mathrm{Zr}$, for which 23 samples had measurable amounts]

\begin{tabular}{|c|c|c|c|c|}
\hline \multirow[b]{2}{*}{ Constituent } & \multicolumn{2}{|c|}{ Geometric mean } & \multirow{2}{*}{\multicolumn{2}{|c|}{$F$ value }} \\
\hline & $\begin{array}{c}\text { Washed } \\
\text { grass }\end{array}$ & $\begin{array}{c}\text { Unwashed } \\
\text { grass }\end{array}$ & & \\
\hline $\begin{array}{l}\mathrm{Ash}^{1} \ldots \ldots \ldots \\
\mathrm{Ag} \ldots \ldots \ldots \\
\mathrm{A} 1^{1} \ldots \ldots \ldots \\
\mathrm{B} \ldots \ldots \ldots \ldots \\
\mathrm{Ba} \ldots \ldots \ldots\end{array}$ & $\begin{array}{c}6.7 \\
2.7 \\
.54 \\
70 \\
340\end{array}$ & $\begin{array}{r}8.6 \\
6.1 \\
1.4 \\
100 \\
400\end{array}$ & $\begin{array}{c}34 \\
92 \\
117 \\
20 \\
1.5\end{array}$ & $\begin{array}{l}* * \\
* * \\
* * \\
* *\end{array}$ \\
\hline 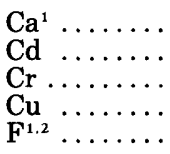 & \begin{tabular}{l}
\multicolumn{4}{c}{.5} \\
57 \\
78 \\
72 \\
$\quad .0050$
\end{tabular} & $\begin{array}{l}3.9 \\
82 \\
200 \\
66 \\
.0167\end{array}$ & $\begin{array}{r}0.8 \\
13 \\
55 \\
2 \\
155\end{array}$ & $\begin{array}{l}* * \\
* * \\
* *\end{array}$ \\
\hline $\begin{array}{l}\mathrm{Fe}^{1} \ldots \ldots \ldots \\
\mathrm{Mg}^{1} \ldots \ldots \ldots \\
\mathrm{Mn} \ldots \ldots \ldots \\
\mathrm{Mo} \ldots \ldots \ldots \\
\mathrm{Ni} \ldots \ldots \ldots\end{array}$ & $\begin{array}{l}.35 \\
1.4 \\
320 \\
22 \\
16\end{array}$ & $\begin{array}{l}.74 \\
1.0 \\
320 \\
21 \\
28\end{array}$ & $\begin{array}{r}41 \\
11 \\
0 \\
0 \\
22\end{array}$ & $\begin{array}{l}* * \\
* * \\
* *\end{array}$ \\
\hline $\begin{array}{l}\mathrm{P} \ldots \ldots \ldots \ldots \\
\mathrm{Pb} \\
\mathrm{Pb} \\
\mathrm{Se}^{2} \ldots \ldots \ldots \ldots \\
\text { Si } \ldots \ldots \ldots \ldots \\
\text { Sr } \ldots \ldots \ldots \ldots\end{array}$ & $\begin{array}{c}11,300 \\
79 \\
1.3 \\
390,100 \\
250\end{array}$ & $\begin{array}{c}12,400 \\
110 \\
1.6 \\
380,400 \\
190\end{array}$ & $\begin{array}{c}2 \\
21 \\
7.4 \\
0 \\
8\end{array}$ & $\begin{array}{r}* * \\
* \\
*\end{array}$ \\
\hline $\begin{array}{l}\mathrm{Ti}^{{ }^{1}} \ldots \ldots \ldots \\
\mathrm{U} \ldots \ldots \ldots \\
\mathrm{V} \ldots \ldots \ldots \\
\mathrm{Zn} \ldots \ldots \ldots \\
\mathrm{Zr} \ldots \ldots \ldots\end{array}$ & $\begin{array}{l}.020 \\
4.1 \\
230 \\
920 \\
29\end{array}$ & $\begin{array}{l}\quad .054 \\
6.1 \\
280 \\
920 \\
54\end{array}$ & $\begin{array}{c}41 \\
14 \\
3 \\
0 \\
8.3\end{array}$ & $\begin{array}{l}* * \\
* *\end{array}$ \\
\hline
\end{tabular}

'Values in percent

${ }^{2}$ Value determined on dry materal. 
The presence of apatite, shown by X-ray diffractograms of the dried plant-wash residue, suggests that the concentrations of calcium and phosphorus should, like fluorine, have differed significantly in washed and unwashed samples. The fact that they did not is possibly because these two elements are major constituents of the plants that were studied, and any additional amount present on the unwashed samples probably is relatively small compared to the total content of these elements in the plants.

Although the washed samples in this comparison study were more rigorously cleaned than they would be in nature, animals grazing near the processing operations following a heavy rain may be less likely to consume high levels of certain potentially toxic trace elements such as cadmium, chromium, fluorine, nickel, and silver. This comparison also demonstrates that precipitation may account for the highly variable fluorine values obtained on different sampling dates in the University of Idaho studies (University of Idaho, 1955-74). The great differences observed in our study between washed and unwashed plant samples exemplify the need to consider carefully the objectives of any sampling program conducted near a point source of emissions. The analysis of washed samples reveals the presence of elements largely incorporated by the plants-the type of information necessary to determine the concentrations of elements, suspected to be related to some emission source, that are potentially toxic to the plants. The analysis of unwashed forage plants, however, is more important in veterinary toxicology, but such analysis should consider the frequency of natural cleansing mechanisms (relative to sampling times).

\section{IMPACT OF ELEMENT EMISSIONS ON PLANT HEALTH}

In this report we correlate elevated levels of seven elements in vegetation as being significantly associated with phosphate-processing operations. Table 11 lists cases described in the literature where these and two additional elements, considered to be important in this study, have been demonstrated to be toxic to plants under both natural and man-induced conditions. (Table 1 lists the scientific names of the plants mentioned by their common names in table 11.)

Of the nine elements considered in table 11 , chromium, nickel, and selenium generally are most toxic if absorbed from the soil. Fluorine, which is moderately toxic to plants if absorbed through the roots, is highly toxic if absorbed through foliage. The remaining five elements (cadmium, lithium, uranium, vanadium, and zinc) have little toxic effect under natural conditions. Radiation from uranium ore, however, was thought to have caused mutations in plants (Shacklette, 1962, 1964). Even under maninduced conditions, the relative toxicity of these lastmentioned five elements is considered to be low.

In this study, we did not attempt to identify specific plants having symptoms of element toxicity. The concentrations of toxic elements in plants presented in table 8 may be compared to levels of toxicity given in table 11. Several interdependent extrinsic and intrinsic factors influence relative element toxicity: (1) the genetics of the plant involved (differences being found even between varieties), (2) the availability of the emission-related elements to the plant, (3) the distance from the processing operations, and (4) the climate of the area. The values in table 8 indicate that, of the nine elements suspected as being contributed to vegetation $3 \mathrm{~km}$ from phosphate-processing operations, only chromium and zinc have concentration ranges known to be toxic to some plants. Fluorine may also affect plants but probably only along downwind transects. As discussed earlier, relatively high values for these elements occur only within about $4 \mathrm{~km}$ of the processing sites. Outside this zone, element concentrations in tissue are probably not sufficiently high to produce toxicity symptoms.

Even if conditions favor the development of toxicity symptoms in plants near the processing operations, the exact cause of the symptoms would remain uncertain. For example, Brewer (1966, p. 181) stated: "Although fluoride toxicity symptoms are relatively characteristic, a number of other factors, such as excessive salts, extreme moisture stress, and certain mineral deficiencies, will produce similar symptoms. For this reason, visual diagnosis must usually be confirmed by chemical analysis of the leaves or other plant tissues."

\section{IMPACT OF ELEMENT EMISSIONS ON ANIMAL HEALTH}

Since the early 1950's, farmers and ranchers have charged that the health of the livestock grazing near phosphate-processing operations at Soda Springs was being affected (Ben Gomm, U.S. Bureau of Land Management, written commun., 1976). Losses from fluorosis have been documented, and financial settlements for individual animals and, in some cases, whole herds have been made. All occurrences of fluorosis were reported from locations relatively near the processing plant and presumably were the result of the ingestion of forage having high concentrations of fluorine. Studies by scientists of the University of Idaho College of Agriculture (University of Idaho, 1955-74), have confirmed the existence of high levels of fluorine in alfalfa and grasses and certain cultivated 
plants near the processing sites at Pocatello and Soda Springs.

Comparison of tables 8 and 11 shows that fluorine may have concentrations in sagebrush and cheatgrass that are high enough to produce fluorosis in horses and cattle. Of the other elements, cadmium may be sufficiently high to affect the growth of sheep. The concentrations of chromium, vanadium, and zinc are high and under certain circumstances could be toxic. The concentrations of lithium, nickel, selenium, and uranium are relatively low in the plants sampled and probably pose an insignificant health hazard.

As with plant toxicity, the potential toxicity of these elements to grazing animals in the area depends on several factors: (1) the species and feeding habit of the animal (horses and sheep are more likely than cattle to consume contaminated soil as well as plants); (2) the animal's diet (a diet of predominantly perennial, as opposed to annual, plants likely would contain higher concentrations of the contaminants; supplemental feeds imported from outside the area would lessen the impact of locally grown forage); (3) the distance between animal grazing and emission source (an animal grazing more than $8 \mathrm{~km}$ from a source is unlikely to consume highly contaminated forage); (4) the season of the year (contaminants are more likely to be concentrated in forage plants at the end of the growing season than at the beginning), (5) the general activity of the phosphate-processing operations through time; (6) the winds and their influence on the distribution of emissions, which tend to settle out more downwind than upwind; and (7) the amount, form, and frequence of precipitation, which may wash and therefore dilute the surface contamination of forage.

\section{SUMMARY}

1. The concentrations of several elements in plants and soils tend to increase nearer the phosphateprocessing operations. The southwest wind vector at Pocatello is the predominant vector; therefore, we found most of the significant relations between concentrations and processing emissions along the northeast (downwind) transect. At Soda Springs, both transect directions had strong wind vectors, although the wind is more frequent from the southeast. In the plants sampled near Soda springs, we found significant relations along both transect directions, but the more significant ones were along the northwest transect; in the soils, relations may have been obscured by the variability of the soil materials sampled.

2. The concentrations of cadmium, chromium, fluorine, selenium, uranium, vanadium, and zinc in plants were significantly associated with phosphate- processing operations. Lithium and nickel had frequent importance, and phosphorus and sodium had infrequent and questionable importance. Cadmium, chromium, fluorine, uranium, vanadium, and zinc had unusually high concentrations within $4 \mathrm{~km}$ of the processing sites. Concentrations of fluorine and uranium were highest at Pocatello; those of cadmium and zinc were highest at Soda Springs. Element content in plants decreased most precipitously within about $4 \mathrm{~km}$ of the processing sites and continued to decrease steadily but less dramatically as far as 16 to $32 \mathrm{~km}$ from the sites.

3. In general, sagebrush reflected higher concentrations of element emissions from the processing operations than did grasses.

4. In the A-horizon soils along the northeast (downwind) transect at Pocatello, beryllium, fluorine, iron, lead, lithium, potassium, rubidium, thorium, and zinc are interpreted as being significantly related to phosphate processing. Southwest (upwind) of Pocatello, the concentrations of iron and zinc in A-horizon soil decreased with increasing distance from the emission sources, but we believe that only zinc is possibly associated with the emissions.

5. Both transects at Soda Springs showed many conflicting relations in A-horizon soils, the element concentrations in some cases increasing with increasing distance from the emission sources; in others, decreasing. Because of these conflicts, we could not determine with confidence which relations, if any, were caused by the processing emissions.

6. We interpret all relations in C-horizon soils along all transects as not being caused by processing emissions.

7. We could discern no clear patterns for relations between the content of any element in the ash of plants and the total concentration of that element in A-horizon soils for any transect at either study area. Therefore, we could make no generalizations about plant uptake of emission-related elements from the soil or about the availability of these elements to plants.

8. Of the nine elements (cadmium, chromium, fluorine, lithium, nickel, selenium, uranium, vanadium, and zinc) commonly added to vegetation near phosphate-processing operations, the concentrations of only chromium, zinc, and possibly fluorine are within the ranges documented as being toxic to some plants. These high levels generally occur only downwind and within $8 \mathrm{~km}$ of the processing operations. In this study, however, we did not try to identify instances of toxicity of these or any other elements in the plants studied. 
9. Of the same nine elements commonly added to vegetation near the processing sites, we speculate that only cadmium and fluorine may be present in sufficiently high concentrations, at some times and under certain circumstances, to be toxic to grazing animals. However, chromium, vanadium, and zinc concentrations are also high, and these elements could potentially be toxic. Of these five elements, only fluorine has been positively implicated with adverse effects on animal health. As in the soils, the high concentrations of these five elements are generally downwind and within $8 \mathrm{~km}$ of the processing operations. Additional studies are needed to assess adequately the effects of element emissions from phosphate processing on animal and human health.

10. By comparing the chemistry of washed and unwashed grass samples collected $2 \mathrm{~km}$ downwind of an elemental-phosphorus plant at Soda Springs, we discovered that the unwashed samples had significantly higher concentrations of 13 elements, most of which are considered to be environmentally important. Periodic cleansing by rainfall may alter appreciably the concentration of elements consumed by grazing animals. Washed plants contained high concentrations of the potentially toxic elements fluorine and silver, and unwashed samples contained as much as three times these concentrations.

\section{REFERENCES CITED}

Aldrich. D. G., Vanselow, A. P., and Bradford, G. R., 1951, Lithium toxicity in citrus: Soil Sci., v. 71, no. 4, p. 291-295.

Allaway, W. H., 1968, Agronomic controls over the environmental cycling of trace elements, volume 20 of A. G. Norman, ed., Advances in agronomy: New York Academic Press, p. 235-274.

Bowen, H. J. M., 1966, Trace elements in biochemistry: New York, Academic Press, 241 p.

Brewer, R. F., 1966, Fluorine, in H. D. Chapman, ed., Diagnostic criteria for plants and soils: Riverside, California Univ. Div. Agr. Sci., p. 180-196.

Brooks, R. R., 1972, Geobotany and biogeochemistry in mineral exploration: New York, Harper and Row, $290 \mathrm{p}$.

Cannon, H. L., 1955, Geochemical relations of zinc-bearing peat to the Lockport Dolomite, Orleans County, New York: U.S. Geol. Survey Bull. 1000-D, p. 119-185.

1960, The development of botanical methods of prospecting for uranium in the Colorado Plateau: U.S. Geol. Survey Bull. 1085-A, p. 1-50.

1964, Geochemistry of rocks and related soils and vegetation in the Yellow Cat area, Grand County, Utah: U.S. Geol. Survey Bull. 1176, 127 p.

1971, The use of plant indicators in ground water surveys, geologic mapping, and mineral prospecting: Taxon, v. 20, no. 2/3, p. 227-256.

Cramer, H. E., and Bowers, J. F., 1974, Calculated impact on ambient air quality of current and projected sulfur dioxide and fluorine emissions from the Agricultural Products Corporation plant at Conda, Idaho: Research Triangle Park, N.C., U.S. Environmental Protection Agency TR 74-103-01.
Davis, J. C., 1973, Statistics and data analysis in geology: New York, John Wiley and Sons, Inc., $550 \mathrm{p}$.

University of Idaho, 1955-74, Fluorine studies in the Pocatello and Soda Springs areas: Moscow, Idaho Univ. Coll. Agriculture, Dept. of Bacteriology and Biochemistry, published annually.

Doyle, J. J., Pfander, W. H., Grebing, S. E., and Piercer, J. O., 1972, Effects of dietary cadmium on growth and tissue levels in sheep, in D. D. Hemphill, ed., Trace substances in environmental health-VI: Columbia, Missouri Univ., 6th Ann. Conf. on Trace Substances in Environmental Health, Columbia, MO. 1972, Proc., p. 181-186.

Fleischer, Michael, Sarofim, A. F., Fassett, D. W., Hammond, Paul, Shacklette, H. T., Nisbet, I. C. T., and Epstein, Samuel, 1974, Environmental impact of cadmium-A review by the panel on hazardous trace substances: Environmental Health Perspectives, v. 7, p. 253-323.

Ganje, T. J., 1966, Selenium, in H. D. Chapman, ed., Diagnostic criteria for plants and soils: Riverside, California Univ. Div. Agr. Sci., p. 394-404.

Gough, L. P., and Severson, R. C., 1976, Impact of point source emissions from phosphate processing on the element content of plants and soils, Soda Springs, Idaho, in D. D. Hemphill, ed., Trace substances in environmental health-X: Columbia, Missouri Univ. 10th Ann. Conf. on Trace Substances in Environmental Health, Columbia, Mo., 1976, Proc., p. 225-233.

Gough, L. P., and Shacklette, H. T., 1976, Toxicity of selected elements to plants, animals, and man-An outline: U.S. Geol. Survey Open-file Rept. 76-746, 46 p.

Harms, T. F., and Papp, C. S. E., 1975, Analysis of plants or plant ash by methods other than emission spectroscopy, in Geochemical survey of the western coal regions, second annual progress report, July 1975: U.S. Geol. Survey Open-file Rept. 75-436, p. 74-78.

Huffman, Claude, Jr., 1975, Analysis of rocks and soils for total content of sodium, magnesium, lithium, rubidium, zinc, cadmium, mercury, fluorine, and carbon, in Geochemical survey of the western coal regions, second annual progress report, July 1975: U.S. Geol. Survey Open-file Rept. 75-436, p. 71-73.

Kuichler, A. W., 1964, Potential natural vegetation of the conterminous United States: Am. Geog. Soc. Spec. Pub. 36, 116 p.

Lewis, G. C., Fosberg, M. A., McDole, R. E., and Chugg, J. C., 1975, Distribution and some properties of loess in southcentral and southeastern Idaho: Soil Sci. Soc. America Proc., v. 39, no. 6, p. $1165-1168$.

Lewis, T. R., 1972, Effects of air pollution on livestock and animal products, in Helena Valley, Montana, area environmental pollution study: U.S. Environmental Protection Agency Office of Air Programs Pub. AP-91, p. 113-124.

Malyuga, D. P., 1964, Biogeochemical methods of prospecting: New York, Consultants Bureau, 205 p. [translation from the Russian].

McMurtrey, J. E., and Robinson, W. O., 1938, Neglected soil constituents that affect plant and animal development, in Soils and men: U.S. Dept. Agriculture Yearbook, 1938, p. 807-829.

Melton, J. R., Ellis, B. G., and Doll, E. C., 1970, Zinc, phosphorus, and lime interactions with yield and zinc uptake by Phaseolus vulgaris: Soil Sci. Soc. America Proc., v. 34, no. 1, p. 91-93.

Mertz, Walter, chm., and others, 1974a, Chromium, in Geochemistry and the environment, volume 1 , The relation of selected trace elements to health and disease: Washington, D.C., Natl. Acad. Sci., p. 29-35. 
1974b, Lithium, in Geochemistry and the environment, volume 1, The relation of selected trace elements to health and disease; Washington, D.C., Natl. Acad. Sci., p. 36-42.

Meyers, A. T., Havens, R. G., and Dunton, P. J., 1961, A spectrochemical method for the semiquantitative analysis of rocks, minerals, and ores: U.S. Geol. Survey Bull. 1084-I, p. 207-229.

Miesch, A. T., 1967, Theory of error in geochemical data: U.S. Geol. Survey Prof. Paper 574-A, p. A1-A17.

Miesch, A. T., and Huffman, Claude, Jr., 1972, Abundance and distribution of lead, zinc, cadmium, and arsenic in soils, in Helena Valley, Montana, area environmental pollution study: U.S. Environmental Protection Agency Office of Air Programs Pub. AP-91, p. 65-80.

Millard, H. T., Jr., 1975, Determinations of uranium and thorium in rocks and soils by the delayed neutron technique, in Geochemical survey of the western coal regions, second annual progrss report, July 1975: U.S. Geol. Survey Open-file Rept. 75-436, p. 79-81.

Mitchell, R. L., 1964, Trace elements in soils, in F. E. Bear, ed., Chemistry of the soil [2nd ed.]: New York, Van Nostrand Reinhold Co., p. 320-368.

National Research Council, 1974, Effects of fluorides in animals: Washington, D.C., Natl. Acad. Sci., Natl. Research Council, Committee on Animal Nutrition, Subcommittee on Fluorosis, $70 \mathrm{p}$.

National Research Council, 1971, Fluorides: Washington, D.C., Natl. Acad. Sci., Natl. Research Council, Committee on Biologic Effects of Atmospheric Pollutants, 295 p.

Oldfield, J. E., chm., and others, 1974, Selenium, in Geochemistry and the environment, volume 1 , The relation of selected trace elements to health and disease: Washington, D.C., Natl. Acad. Sci., p. 57-63.

Page, A. L., Bingham, F. T., and Nelson, C., 1972, Cadmium absorption and growth of various plant species as influenced by solution cadmium concentration: Jour. Environmental Quality, v. 1, no. 3 , p. $288-291$.

Pratt, P. F., 1966, Vanadium, in H. D. Chapman, ed., Diagnostic criteria for plants and soils: Riverside, California Univ. Div. Agr. Sci., p. 480-483.

Sauchelli, Vincent, 1969, Trace elements in agriculture: New York, Van Nostrand Reinhold Co., 248 p.

Severson, R. C., and Gough, L. P., 1976, Concentration and distribution of elements in plants and soils near phosphate processing factories, Pocatello, Idaho: Jour. Environmental Quality, v. 5 , no. 4, p. 476-482.
Shacklette, H. T., 1962, Field observations of variations in Vaccinium uliginosum L.: Canadian Field-Naturalist, v. 76, p. 162-167.

1964, Flower variation of Epilobium angustifolium L. growing over uranium deposits: Canadian Field-Naturalist, v. 78, no. 1, p. 32-42.

1965, Element content of bryophytes: U.S. Geol. Survey Bull. 1198-D, p. D1-D21.

Shacklette, H. T., Boerngen, J. G., Cahill, J. P., and Rahill, R. L., 1973, Lithium in surficial materials of the conterminous United States and partial data on cadmium: U.S. Geol. Survey Circ. $673,8 \mathrm{p}$.

Shacklette, H. T., Boerngen, J. G., and Keith, J. R., 1974, Selenium, fluorine, and arsenic in surficial materials of the conterminous United States: U.S. Geol. Survey Circ. 692, 14 p.

Shacklette, H. T., Boerngen, J. G., and Turner, R. L., 1971, Mercury in the environment-Surficial materials of the conterminous United States: U.S. Geol. Survey Circ. 644, 5 p.

Shacklette, H. T., Hamilton, J. C., Boerngen, J. G., and Bowles, J. M., 1971, Elemental composition of surficial materials in the conterminous United States: U.S. Geol. Survey Prof. Paper 574-D, $71 \mathrm{p}$.

Shacklette, H. T., Sauer, H. I., and Miesch, A. T., 1970, Geochemical environments and cardiovascular mortality rates in Georgia: U.S. Geol. Survey Prof. Paper 574-C, p. C1-C39.

Soane, B. D., and Saunder, D. H., 1959, Nickel and chromium toxicity of serpentine soils in southern Rhodesia: Soil Sci., v. 88, no. 6, p. 322-330.

Thorarinsson, Sigurdur, 1970, The "Hekla fires"-A preliminary report of the $1970 \mathrm{Mt}$. Hekla volcanic eruption: Washington, D.C., Smithsonian Inst. Center for Shortlived Phenomena, 2 p.

Trelease, S. F., and Beath, O. A., 1949, Selenium-Its geological occurrence and its biological effects in relation to botany, chemistry, agriculture, nutrition, and medicine: New York, published by the authors, $292 \mathrm{p}$.

Underwood, E. J., 1971, Trace elements in human and animal nutrition [3d ed.]: New York and London, Academic Press, 543 p.

U.S. Department of Agriculture, 1962, Identification and nomenclature of soil horizons in Soil survey manual: U.S. Dept. Agriculture Soil Survey Staff, Supp. to Handb. 18, p. 173-188.

Vanselow, A. P., 1966, Nickel, in Chapman, H. D., ed., Diagnostic criteria for plants and soils: Riverside, California Univ. Div. Agr. Sci., p. 302-309.

Wahlberg, J. S., 1975, Analysis of rocks and soils by X-ray fluorescence, in Geochemical survey of the western coal regions, second annual progress report, July 1975: U.S. Geol. Survey Open-file Rept. 75-436, p. 69-70.

Youngs, F. O., Kern, A. J., and Poulson, E. N., 1925, Soil survey of the Soda Springs-Bancroft area, Idaho: U.S. Dept. Agriculture, Ser. 1925, no. 6, p. 8-13. 